Nevada

Environmental Management Operations Activity

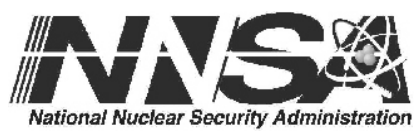

Addendum to the Closure Report for Corrective Action Unit 547:

Miscellaneous Contaminated

Waste Sites,

Nevada National Security Site,

Nevada

Controlled Copy No.:

Revision: 0

July 2013 


\section{DISCLAIMER}

Reference herein to any specific commercial product, process, or service by trade name, trademark, manufacturer, or otherwise, does not necessarily constitute or imply its endorsement, recommendation, or favoring by the United States Government or any agency thereof.

This report has been reproduced directly from the best available copy.

Available for sale to the public from:

U.S. Department of Commerce

National Technical Information Service

5301 Shawnee Road

Alexandria, VA 22312

Telephone: (800) 553-6847

Fax: (703) 605-6900

E-mail: orders@ntis.gov

Online ordering: http://www.ntis.gov/help/ordermethods.aspx

Available electronically at http://www.osti.gov/bridge.

Available for a processing fee to the U.S. Department of Energy and its contractors, in paper, from:

U.S. Department of Energy

Office of Scientific and Technical Information

P.O. Box 62

Oak Ridge, TN 37831-0062

Telephone: (865) 576-8401

Fax: (865) 576-5728

E-mail: reports@adonis.osti.gov 


\title{
ADDENDUM TO THE CLOSURE REPORT FOR CORRECTIVE ACTION UNIT 547: MISCELLANEOUS CONTAMINATED WASTE SITES, NEVADA NATIONAL SECURITY SITE, NEVADA
}

\author{
U.S. Department of Energy \\ National Nuclear Security Administration \\ Nevada Field Office \\ Las Vegas, Nevada
}

Controlled Copy No.

Revision: 0

July 2013 
THIS PAGE INTENTIONALLY LEFT BLANK 


\section{ADDENDUM TO THE CLOSURE REPORT FOR CORRECTIVE ACTION UNIT 547: MISCELLANEOUS CONTAMINATED WASTE SITES, NEVADA NATIONAL SECURITY SITE, NEVADA}

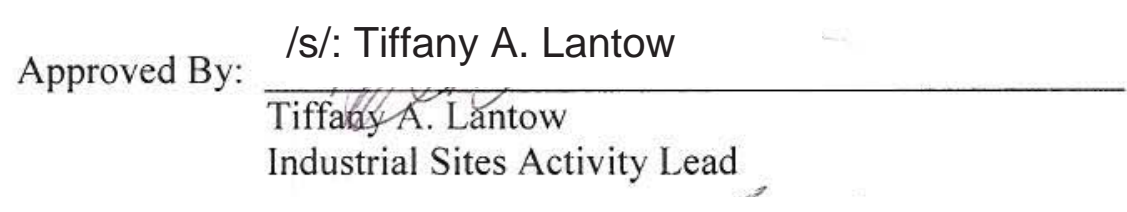

Date: $7 / 29 / 20 / 3$
Approved By: Is/: Robert F. Boehlecke Date: $7 / 30 / / 3$
Robert F. Boehlecke
Environmental Management Operations Activity Manager


THIS PAGE INTENTIONALLY LEFT BLANK 


\section{TABLE OF CONTENTS}

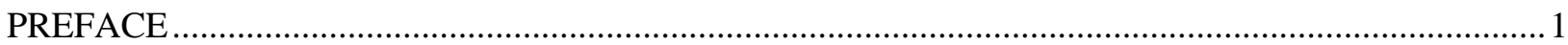

ADDENDUM TO THE CLOSURE REPORT FOR CORRECTIVE ACTION UNIT 547, MISCELLANEOUS CONTAMINATED WASTE SITES ..........................................................

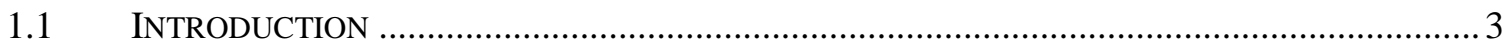

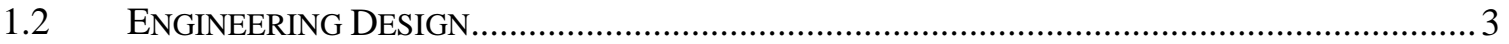

1.2.1 Corrective Action Site 02-37-02, Gas Sampling Assembly (MULLET)............... 4

1.2.2 Corrective Action Site 09-99-06, Gas Sampling Assembly (PLAYER) ................ 4

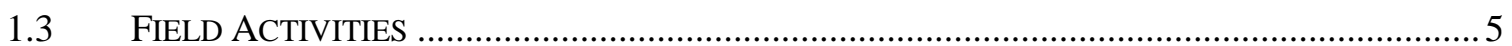

1.3.1 Corrective Action Site 02-37-02, Gas Sampling Assembly (MULLET)............... 5

1.3.2 Corrective Action Site 09-99-06, Gas Sampling Assembly (PLAYER) ................. 5

LIBRARY DISTRIBUTION LIST

\section{APPENDICES}

Appendix A. As-Built Drawings

APPENDIX B. PHOTOGRAPHS 
Addendum to CAU 547 CR

Revision: 0

Date: July 2013

THIS PAGE INTENTIONALLY LEFT BLANK 


\section{PREFACE}

This addendum to the Closure Report for Corrective Action Unit 547: Miscellaneous Contaminated Waste Sites, Nevada National Security Site, Nevada, DOE/NV--1480, dated July 2012, documents repairs of erosion and construction of engineered erosion protection features at Corrective Action Site (CAS) 02-37-02 (MULLET) and CAS 09-99-06 (PLAYER). The final as-built drawings are included in Appendix A, and photographs of field work are included in Appendix B. Field work was completed on March 11, 2013. 
Addendum to CAU 547 CR

Revision: 0

Date: July 2013

THIS PAGE INTENTIONALLY LEFT BLANK 


\section{ADDENDUM TO THE CLOSURE REPORT FOR CORRECTIVE ACTION UNIT 547, MISCELLANEOUS CONTAMINATED WASTE SITES}

This addendum to the Closure Report for Corrective Action Unit 547: Miscellaneous Contaminated Waste Sites, Nevada National Security Site, Nevada, DOE/NV--1480, dated July 2012, documents repairs of erosion and construction of engineered erosion protection features and includes the final as-built drawings.

\subsection{INTRODUCTION}

On August 22, 2012, an unusually high volume of rain fell in a short period of time and caused erosion at Corrective Action Site (CAS) 02-37-02, Gas Sampling Assembly, (hereafter referred to as MULLET) and CAS 09-99-06, Gas Sampling Assembly, (hereafter referred to as PLAYER). At the nearest weather station, 1.13 inches of rainfall was recorded in 12 hours, and the majority of the precipitation (approximately 0.95 inches) occurred in less than 6 hours. There was no damage to the soil covers at these sites. At MULLET, multiple erosion rills formed outside the fence, and less significant erosion occurred near the cover. At PLAYER, significant erosion occurred along the crater slope next to the west side of the cover and at the toe of the cover. Although erosion control features were constructed at PLAYER, including diversion berms at the crater edge, the unusually intense rainfall in a relatively short period of time caused damage in the area between the benches and the cover. Photographs of the erosion damage are included in Appendix B.

In accordance with the Closure Report for Corrective Action Unit (CAU) 547, repairs are to be completed within 90 calendar days of discovery. Since the repair work was significant, a 4-month extension to this deadline was requested by the U.S. Department of Energy, National Nuclear Security Administration Nevada Field Office on October 10, 2012. This extension was granted by the Nevada Division of Environmental Protection (NDEP) on October 22, 2012. With this extension, the deadline for repairs was March 21, 2013.

In the October 22, 2012, letter granting the 4-month extension to the repair deadline, NDEP requested that the plan for erosion control features be certified by a Professional Engineer. A Professional Engineer developed an engineering design that included additional erosion mitigation and runoff control structures for MULLET and PLAYER.

\subsection{ENGINEERING DESIGN}

An engineering design was developed for site restoration and drainage improvements at the MULLET and PLAYER sites. The objectives of the design included repairing existing erosion as well as providing grading and site improvements to control runoff and minimize future risk of erosion or undermining of the covers during a storm event. A hydrologic analysis of the sites that included available rainfall data from National Oceanic and Atmospheric Administration was performed to develop the design. A hydraulic analysis was performed on the proposed drainage ditches and berms to ensure that they would convey water away from the covers. 
The engineering design included new protective berms and drainage ditches, and re-grading of the access roadways to control runoff and minimize erosion. The design was based on the following considerations:

- Feasibility to meet physical and regulatory constraints

- Long-term effectiveness, reliability, and maintenance

- Minimization of capital and lifetime costs

- Constructability given access constraints and available materials

\subsubsection{Corrective Action Site 02-37-02, Gas Sampling Assembly (MULLET)}

Erosion rills were present at the MULLET site downstream, near the cover, and adjacent to the monuments. The objective for this site was to convey water away from the cover to outside the fence line and monuments. To control runoff, the engineering design included three berms on each side of the cover constructed perpendicular to the cover. Berms were placed approximately 40 feet apart at a 1-percent slope towards the crater and compacted. This design minimized flow adjacent to the cover and redirected flow to minimize erosion. The berm design was trapezoidal in cross section with a typical 1-foot height, 2-foot top width, and 3:1 compacted side slope.

\subsubsection{Corrective Action Site 09-99-06, Gas Sampling Assembly (PLAYER)}

Extensive erosion was present at the PLAYER site along the side of the cover down the slope of the crater. The erosion rills were several feet deep, but did not damage the 2-foot protective soil cover. Erosion also occurred along the benches that are used to access the cover. These benches conveyed the storm runoff directly toward the toe of the cover. To minimize the flow adjacent to the cover, a primary drainage channel was designed to convey a majority of the runoff. This channel was designed to be located 25 to 65 feet away from the cover. To redirect flow to the primary channel, significant earthwork was required to fill low points next to the cover. To minimize the amount of fill required, a secondary channel was designed within 5 feet of the toe of the cover to capture runoff from the cover. Both channels were designed to be protected with geotextile fabric and rip rap to minimize flow velocity and erosion caused by runoff. A lined rip rap basin was also to be constructed at the bottom of the crater where the two channels converged.

Both channels were designed to be a minimum of 6 inches deep and 2 feet wide. Channel slopes would follow existing slopes down the crater. Capacity and rip rap calculations for both channels were included in the design. Available rip rap sources located on the NNSS included 6-inch minus rip rap.

Grading along the benches was designed to direct flow to the channels. The benches were to be re-graded to create a flow line along the inside of the bench towards the primary channel. Berms were designed on the outside of each bench to minimize sheet flow down the side of the crater in locations other than the channels.

To minimize run-on from outside the crater, two smaller compacted berms were designed along the crater lip. These berms were designed to extend approximately 50 feet from the cover to direct flow away from the cover at approximately 1 to 2 percent slope. The berm design was trapezoidal in cross section with a typical 1-foot height, 2-foot top width, and 3:1 compacted side slope. 
Several options had been considered for the site restoration and drainage improvements at PLAYER. Removal of the benches was considered, since water had been conveyed along the benches toward the cover and contributed to the erosion near the toe of the cover. However, removal of the benches would increase erosion in the short term and provide no additional long-term benefit. Benches are often designed on steep slopes to break up slopes and allow for shorter slope lengths. To remove the benches and grade the crater slope back to its previous condition would have required additional grading, compaction, and slope stabilization, and the cost would have been significant. Instead, the two drainage paths designed through the benches and the re-grading of the slopes of the benches away from the cover were selected as a more feasible and beneficial solution. It is expected that erosion on the benches will be minimal with regular maintenance. In addition, removal of the benches would inhibit equipment access to the cover on the crater slope for future repairs since the benches are used as access roads to the cover.

Even though the protective soil cover was not damaged, strengthening the existing soil cover was also considered. The soil cover at PLAYER had been evaluated against other options prior to closure of CAU 547 and is the approved design for PLAYER final closure. However, after the erosion occurred, other options were again considered, and the soil cover was determined to be the best option for long-term closure. A more robust cover, such as concrete, poses a threat to damage the pipe and would hide breaches. Additionally, the soil cover is self-sealing and will readily indicate areas where there is settling or other soil movement. These areas can be repaired rapidly and effectively. Additionally, as documented for covers at the NNSS in many instances, the native soil readily seals and forms a desert pavement, thereby effectively protecting the cover against wind and water erosion.

\subsection{Field ACTIVITIES}

On March 11, 2013, repairs of erosion and construction of engineered erosion protection features were completed at MULLET and PLAYER. A site visit was held with NDEP and the engineering subcontractor on March 20, 2013. The following sections provide a summary of field activities at each site.

\subsubsection{Corrective Action Site 02-37-02, Gas Sampling Assembly (MULLET)}

Erosion rills were repaired at MULLET, and berms were constructed on both sides of the cover according to the engineering design to divert water away from the cover. Three berms were constructed perpendicular to the cover on the north, and three berms were constructed perpendicular to the cover on the south. The berms were tested by flowing water over them to simulate runoff and confirm that the water flowed away from the cover. The site was surveyed, and the final as-built drawing is included in Appendix A. Photographs of field work are included in Appendix B. Construction of the berms at MULLET and demobilization from the site was completed on March 11, 2013. No waste was generated during these activities.

\subsubsection{Corrective Action Site 09-99-06, Gas Sampling Assembly (PLAYER)}

At PLAYER, erosion at the toe of the cover was repaired, and erosion protection features were constructed according to the engineering design. The area between the cover and the benches was compacted, and the inner drainage channel was built parallel to the cover down the crater slope. Geotextile fabric and rip rap were placed in the drainage channel. The benches were 
sloped away from the cover and compacted, and berms were constructed on the edges of the benches. The outer drainage channel was built to intersect the low point on the benches.

Geotextile fabric and rip rap were also placed in the outer drainage channel. A drainage basin was constructed in the bottom of the crater where the two drainage channels converged.

Geotextile fabric and rip rap were placed in the drainage basin. Berms were constructed along the crater lip on both sides of the cover. The drainage channels and berms were tested by flowing water over them to simulate runoff and confirm that the water flowed away from the cover. The site was surveyed, and the final as-built drawing is included in Appendix A. Photographs of field work are included in Appendix B. Construction of erosion protection features at PLAYER and demobilization from the site was completed on March 4, 2013. No waste was generated during these activities. 
Addendum to CAU 547 CR

Revision: 0

Date: July 2013

\section{APPENDIX A}

\section{AS-BUILT DRAWINGS}


Addendum to CAU 547 CR

Revision: 0

Date: July 2013

THIS PAGE INTENTIONALLY LEFT BLANK 


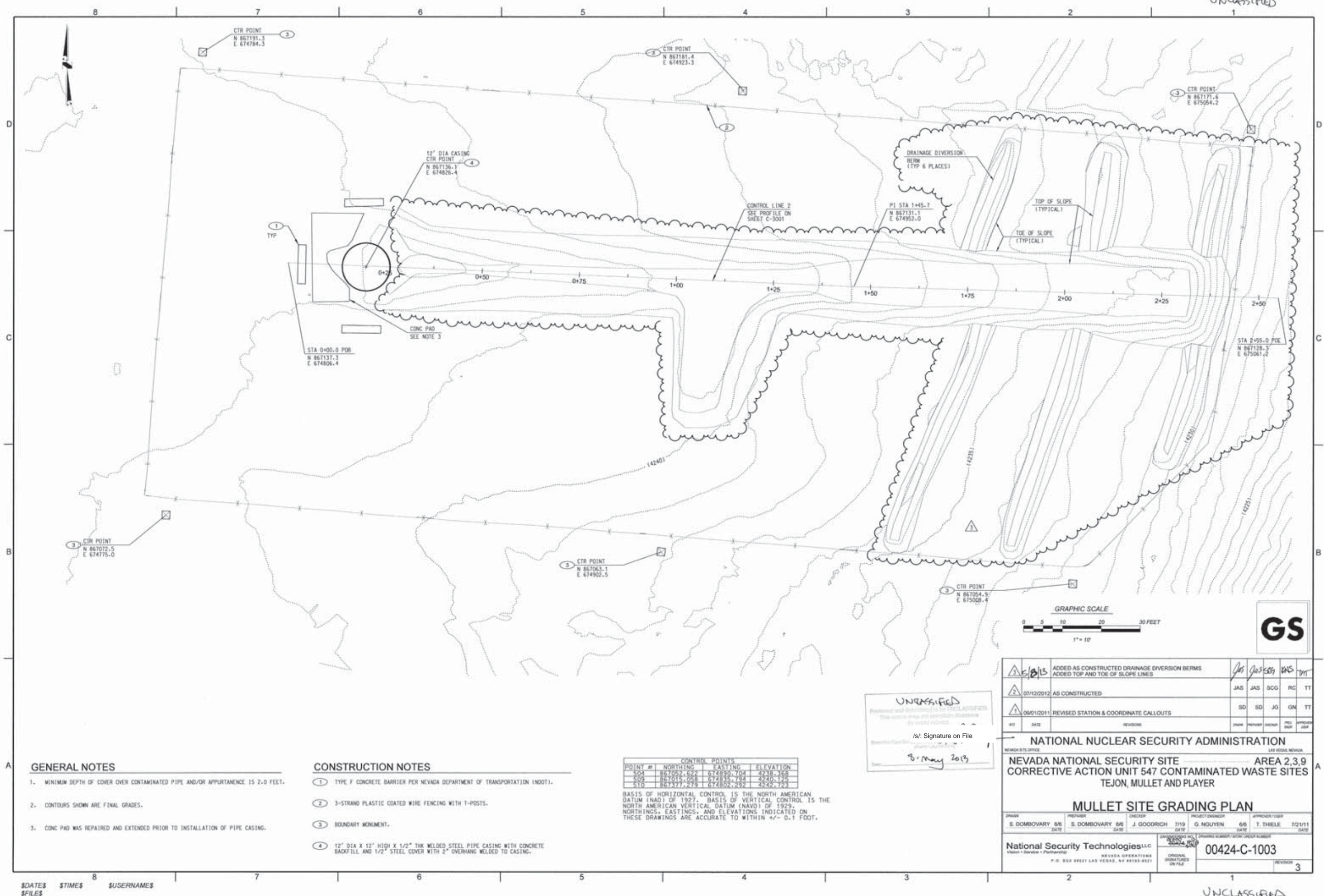




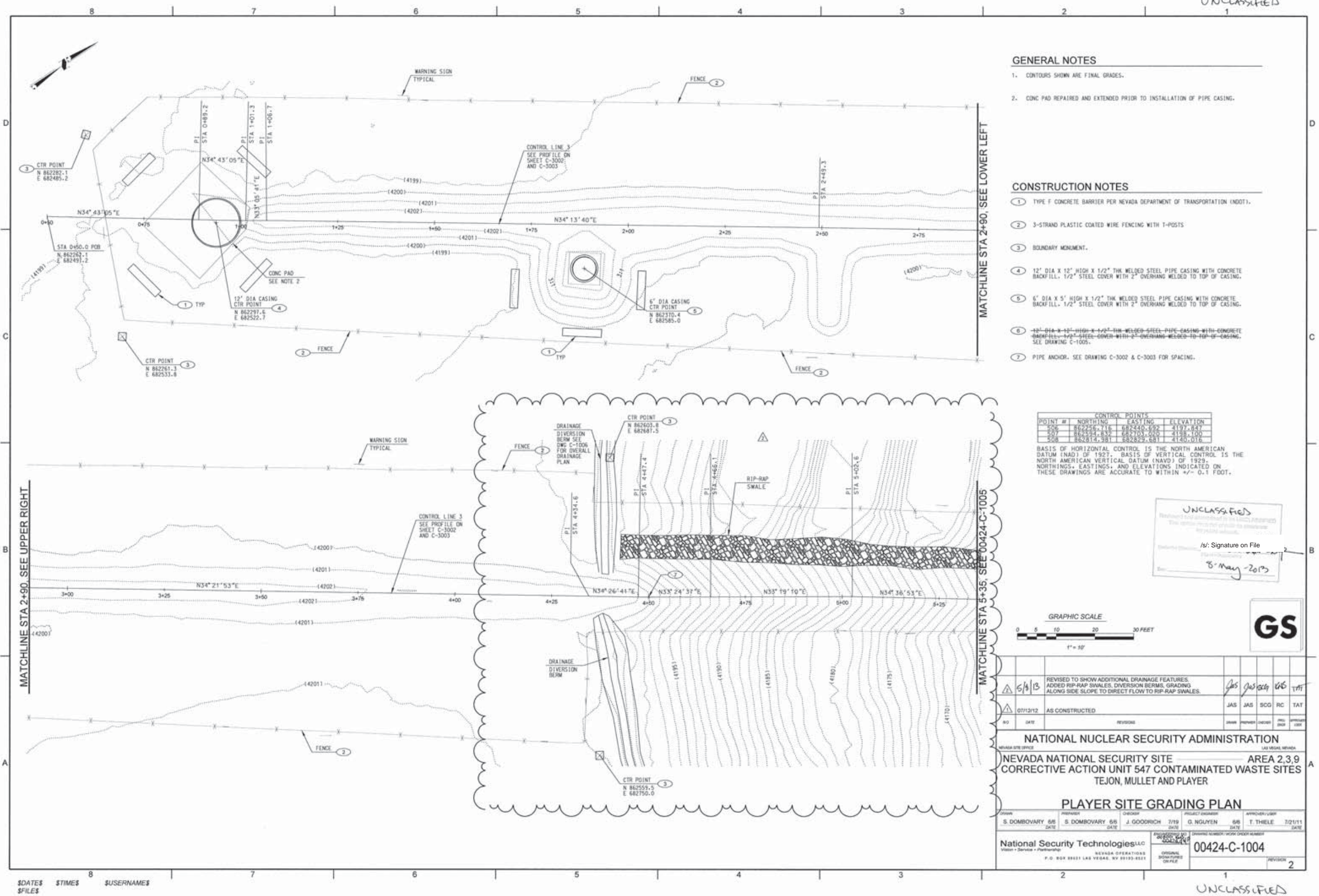




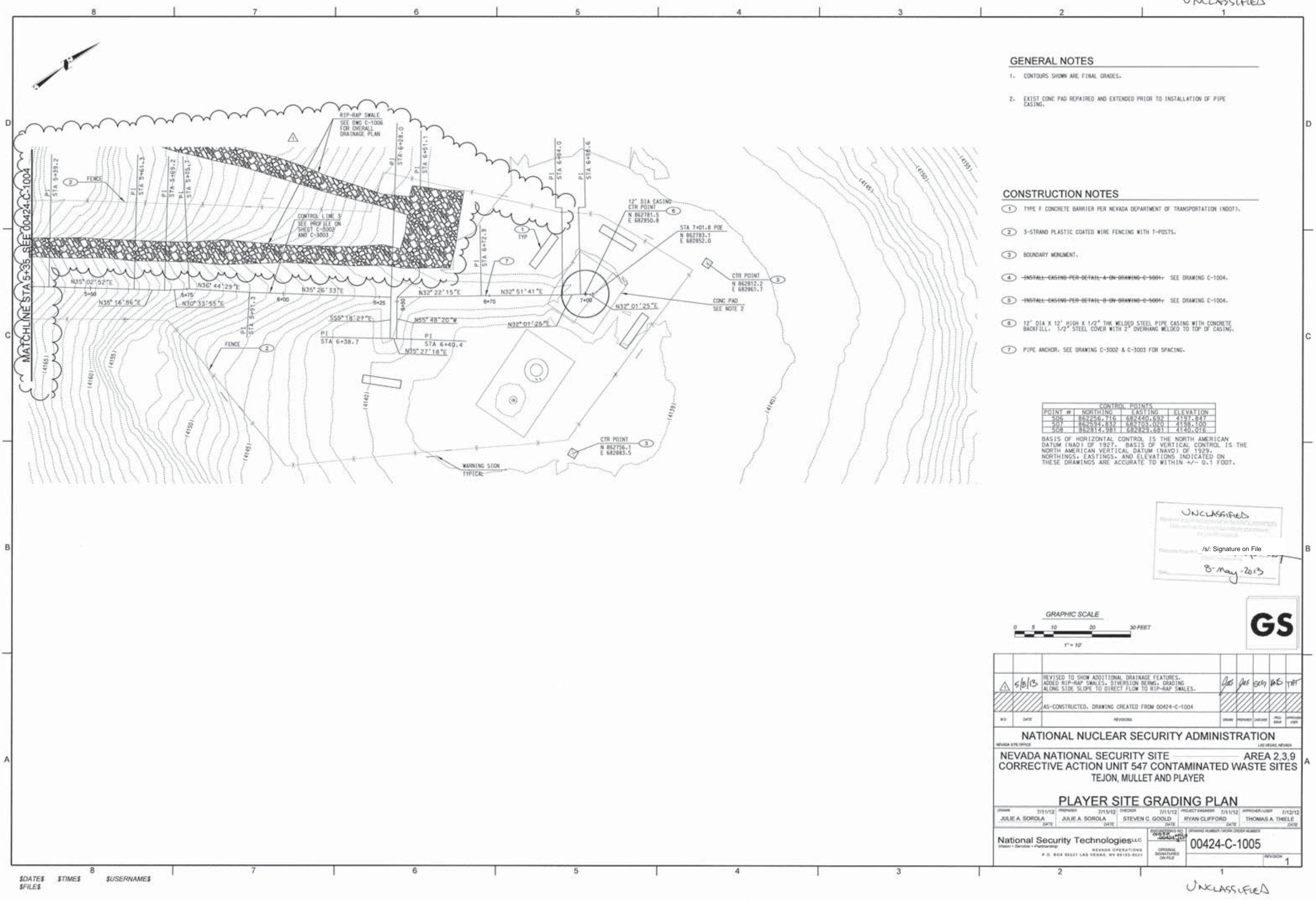




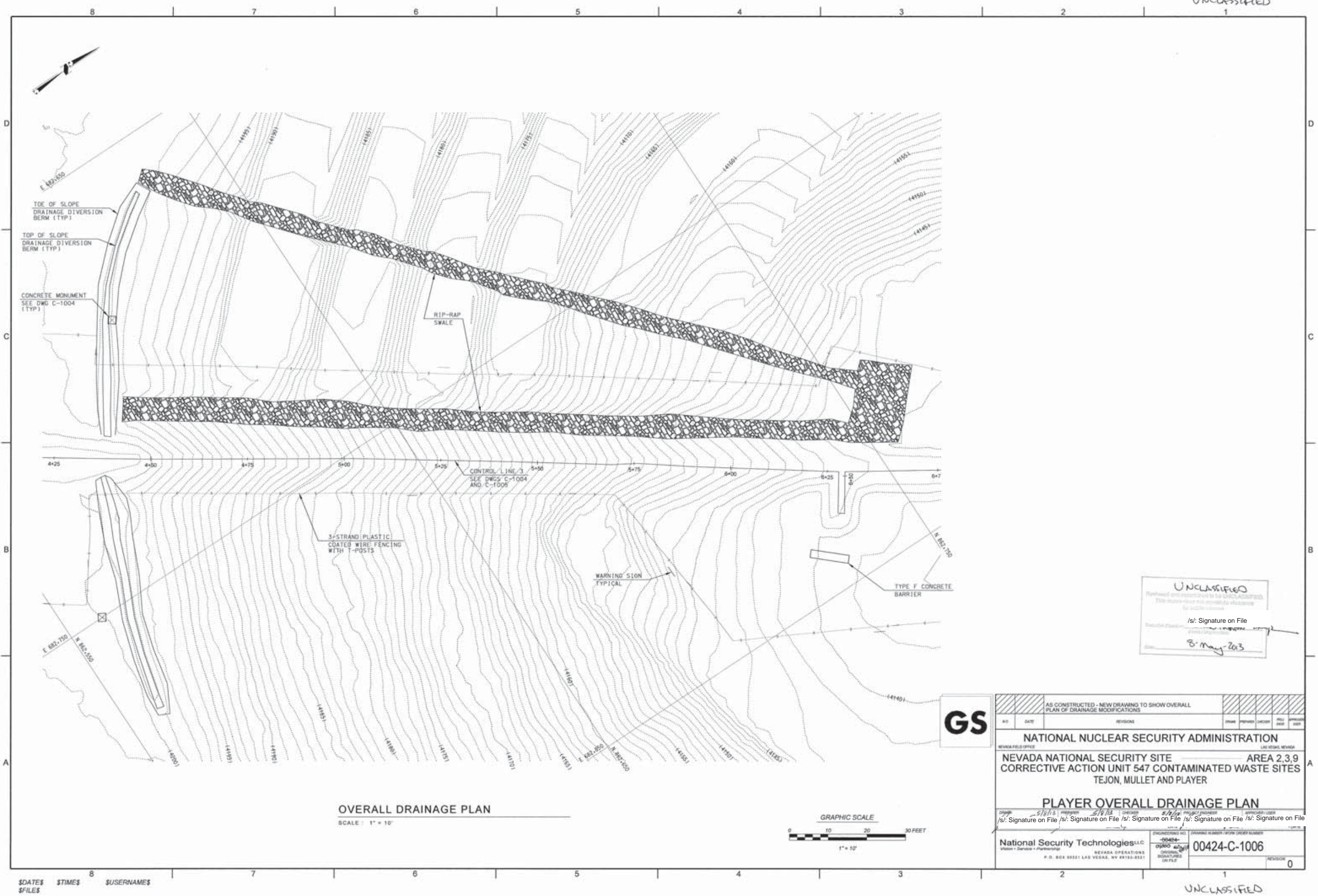


Addendum to CAU 547 CR

Revision: 0

Date: July 2013

\section{APPENDIX B}

\section{PHOTOGRAPHS}


Addendum to CAU 547 CR

Revision: 0

Date: July 2013

THIS PAGE INTENTIONALLY LEFT BLANK 


\section{PHOTOGRAPH LOG}

\begin{tabular}{|c|c|c|}
\hline $\begin{array}{c}\text { PHOTOGRAPH } \\
\text { NUMBER }\end{array}$ & DATE & DESCRIPTION \\
\hline 1 & 08-23-2012 & Erosion Rills at MULLET \\
\hline 2 & 08-23-2012 & Erosion Rills at MULLET \\
\hline 3 & 08-23-2012 & Erosion Rills at MULLET \\
\hline 4 & 03-05-2013 & Constructing Berms at MULLET \\
\hline 5 & 03-05-2013 & Constructing Berms at MULLET \\
\hline 6 & 03-05-2013 & Flow Testing the Berms at MULLET \\
\hline 7 & 03-05-2013 & Constructing Berms at MULLET \\
\hline 8 & 03-05-2013 & Constructing Berms at MULLET \\
\hline 9 & 03-06-2013 & Constructing Berms at MULLET \\
\hline 10 & 03-07-2013 & Flow Testing the Berms at MULLET \\
\hline 11 & 08-23-2012 & Erosion at the Toe of the Cover on the Crater Slope at PLAYER \\
\hline 12 & 08-23-2012 & Erosion at the Toe of the Cover on the Crater Slope at PLAYER \\
\hline 13 & 08-23-2012 & Erosion at the Toe of the Cover on the Crater Slope at PLAYER \\
\hline 14 & 08-23-2012 & Erosion at the Toe of the Cover on the Crater Slope at PLAYER \\
\hline 15 & 08-23-2012 & Standing Water at the Bottom of the Crater at PLAYER \\
\hline 16 & 02-13-2013 & Repairing Erosion at PLAYER \\
\hline 17 & 02-13-2013 & Repairing Erosion at PLAYER \\
\hline 18 & 02-13-2013 & Constructing the Inner Drainage Channel at PLAYER \\
\hline 19 & 02-19-2013 & Sloping and Compacting the Benches at PLAYER \\
\hline 20 & 02-19-2013 & Compacting the Benches at PLAYER \\
\hline 21 & $02-25-2013$ & Constructing the Inner Drainage Channel at PLAYER \\
\hline 22 & 02-26-2013 & Geotextile Fabric and Rip Rap in the Inner Drainage Channel at PLAYER \\
\hline 23 & 02-26-2013 & Geotextile Fabric and Rip Rap in the Inner Drainage Channel at PLAYER \\
\hline 24 & 02-26-2013 & Geotextile Fabric and Rip Rap in the Inner Drainage Channel at PLAYER \\
\hline 25 & 02-26-2013 & Compacted Benches and Berms at PLAYER \\
\hline 26 & 02-27-2013 & Constructing the Outer Drainage Channel at PLAYER \\
\hline 27 & 02-27-2013 & Constructing the Outer Drainage Channel at PLAYER \\
\hline 28 & 02-27-2013 & Geotextile Fabric and Rip Rap in the Outer Drainage Channel at PLAYER \\
\hline 29 & 02-28-2013 & Constructing the Drainage Basin at PLAYER \\
\hline 30 & 02-28-2013 & Constructing the Drainage Basin at PLAYER \\
\hline 31 & 02-28-2013 & Geotextile Fabric and Rip Rap in the Drainage Basin at PLAYER \\
\hline 32 & 02-28-2013 & Completed Drainage Channels and Basin at PLAYER \\
\hline 33 & 02-28-2013 & Constructing Berms on the Lip of the Crater at PLAYER \\
\hline 34 & 02-28-2013 & Constructing Berms on the Lip of the Crater at PLAYER \\
\hline 35 & 03-04-2013 & Completed Work at PLAYER \\
\hline
\end{tabular}


Addendum to CAU 547 CR

Revision: 0

Date: July 2013

THIS PAGE INTENTIONALLY LEFT BLANK 


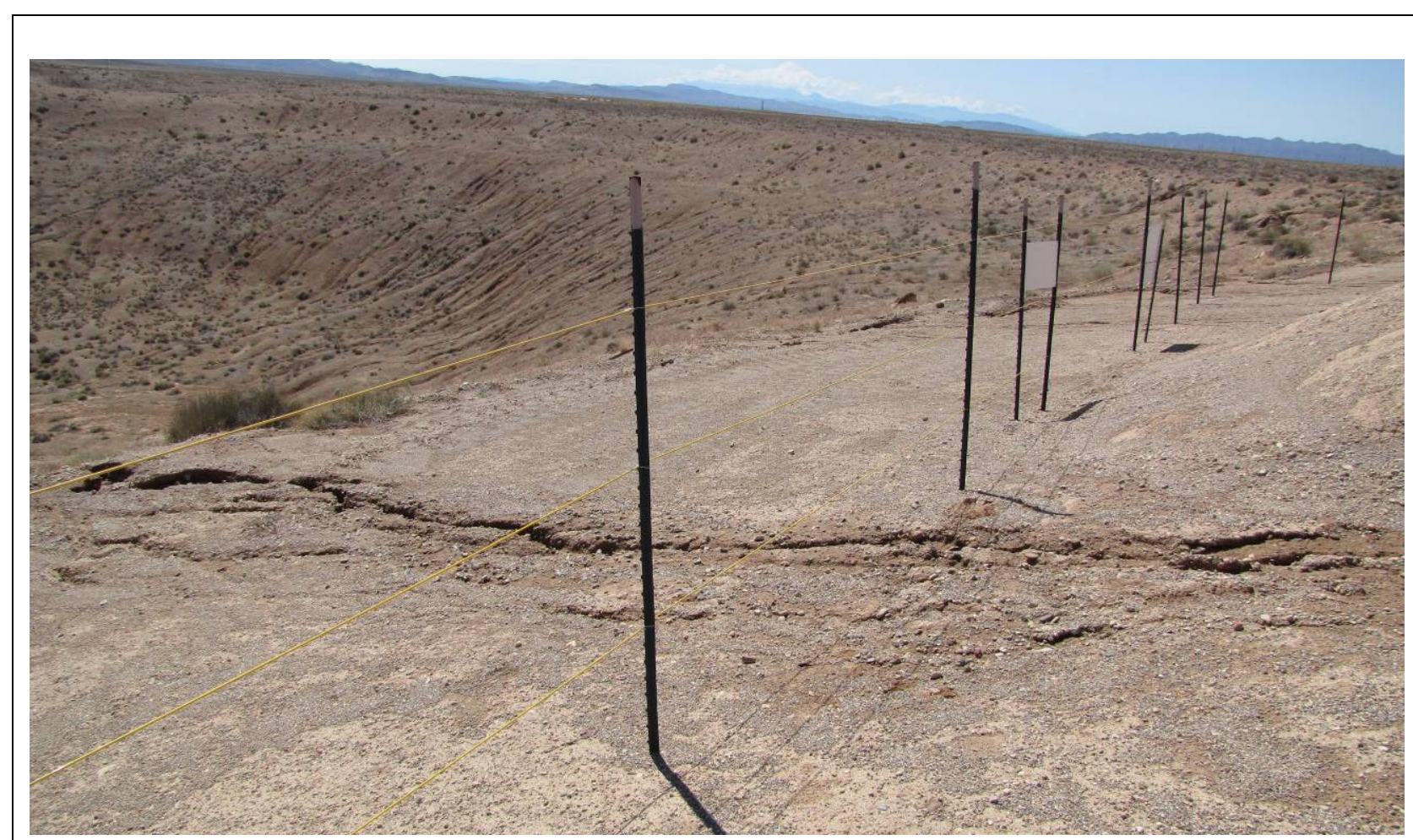

Photograph 1: Erosion Rills at MULLET, 08-23-2012

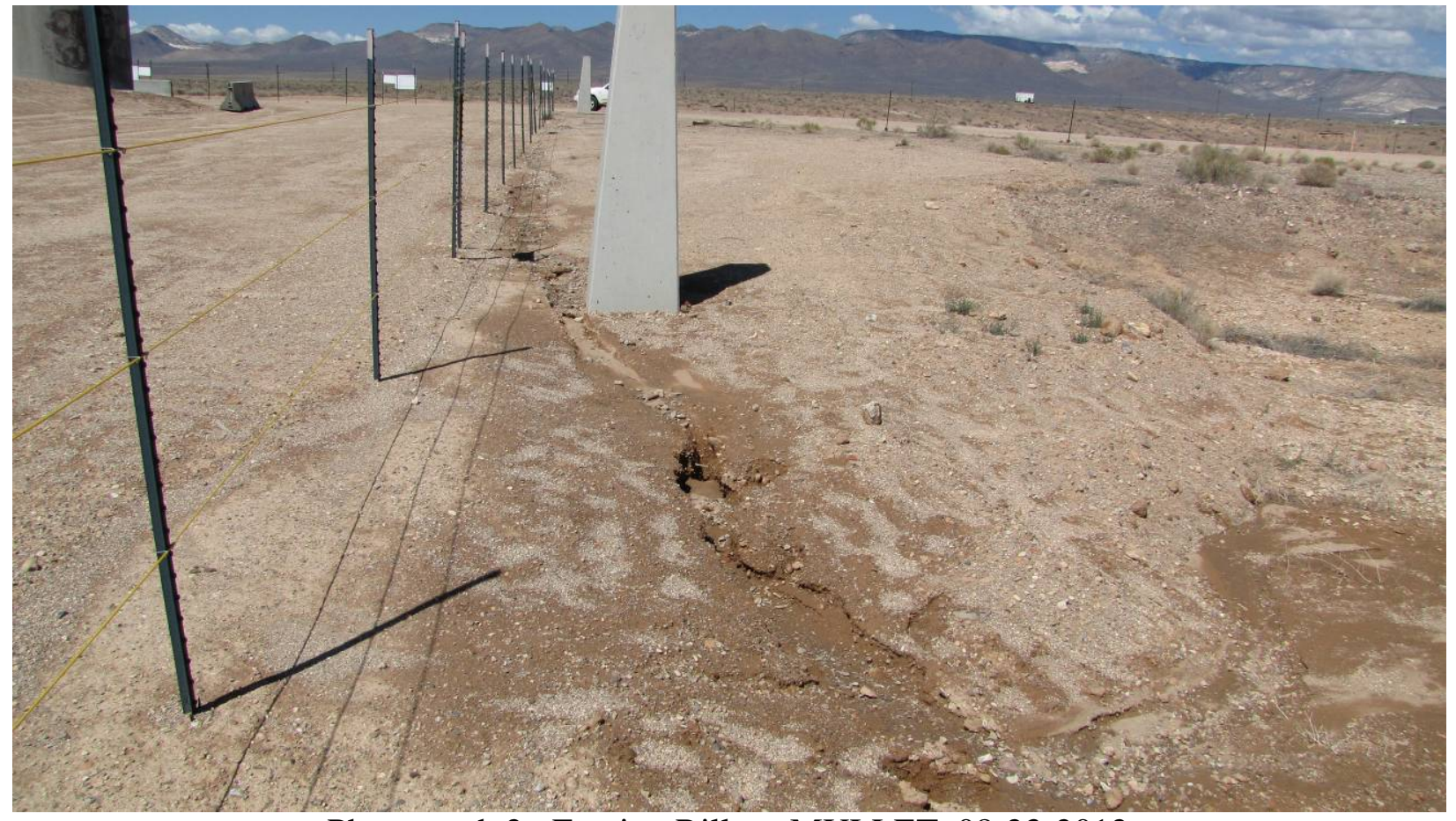

Photograph 2: Erosion Rills at MULLET, 08-23-2012 


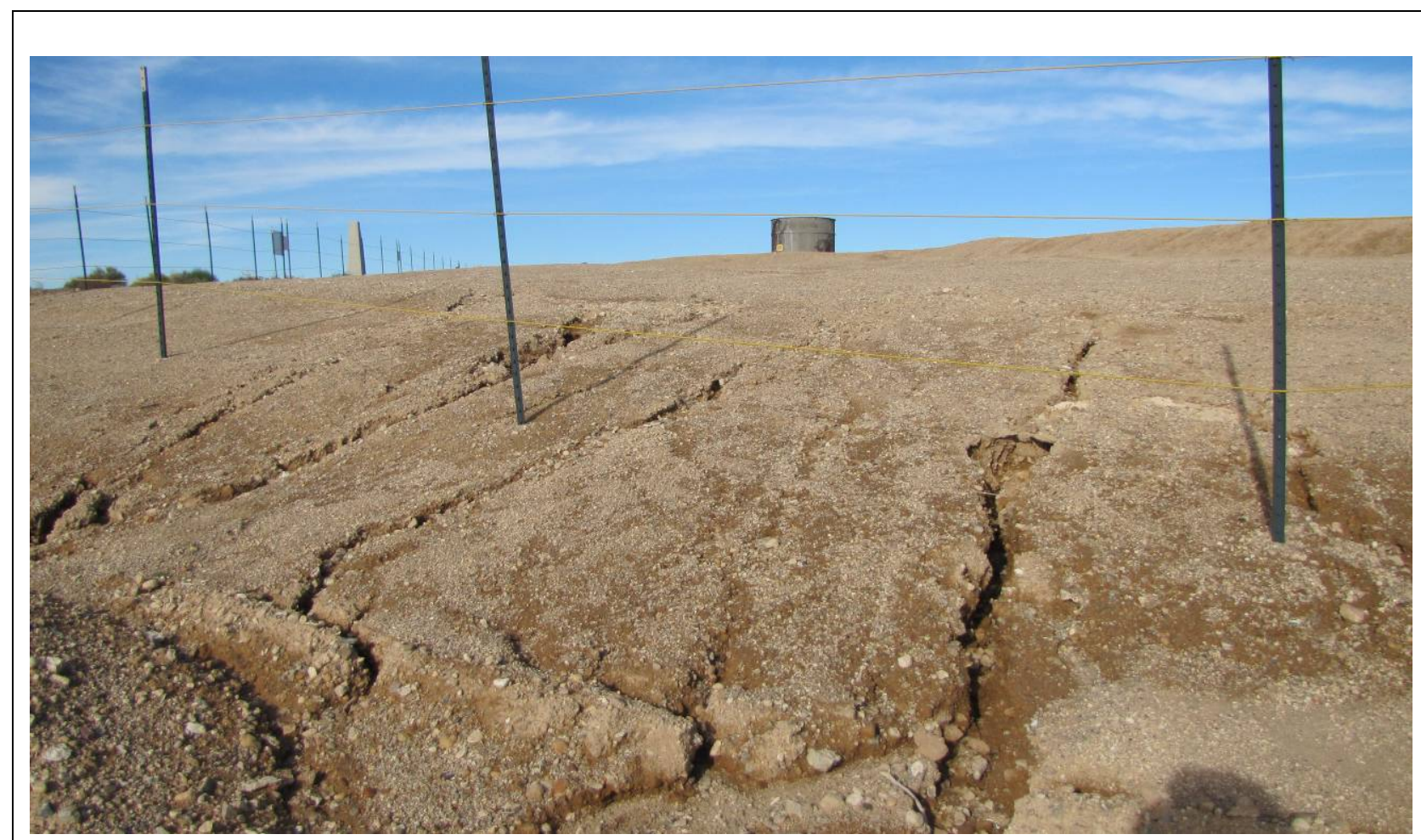

Photograph 3: Erosion Rills at MULLET, 10-15-2012

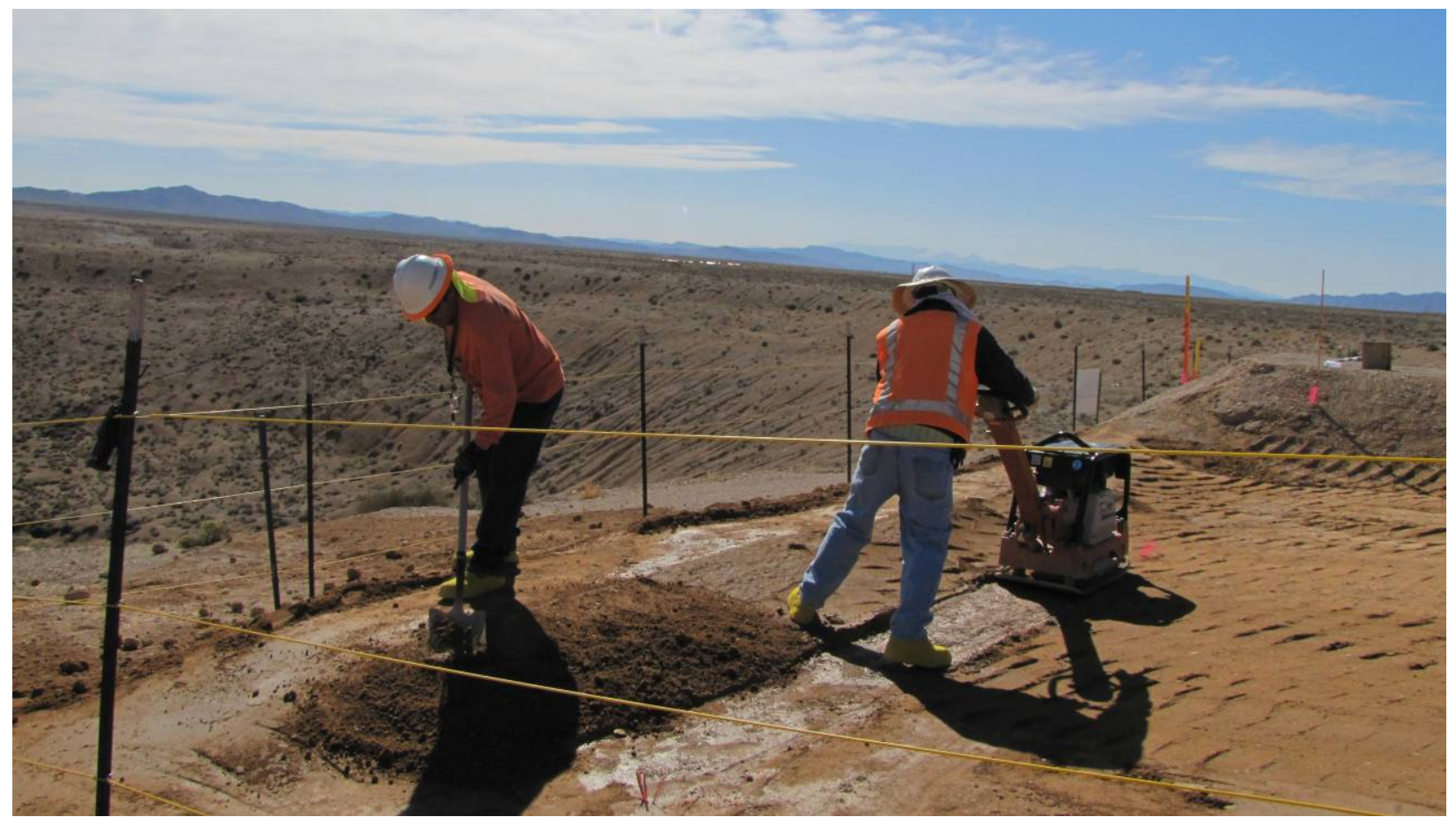

Photograph 4: Constructing Berms at MULLET, 03-05-2013 


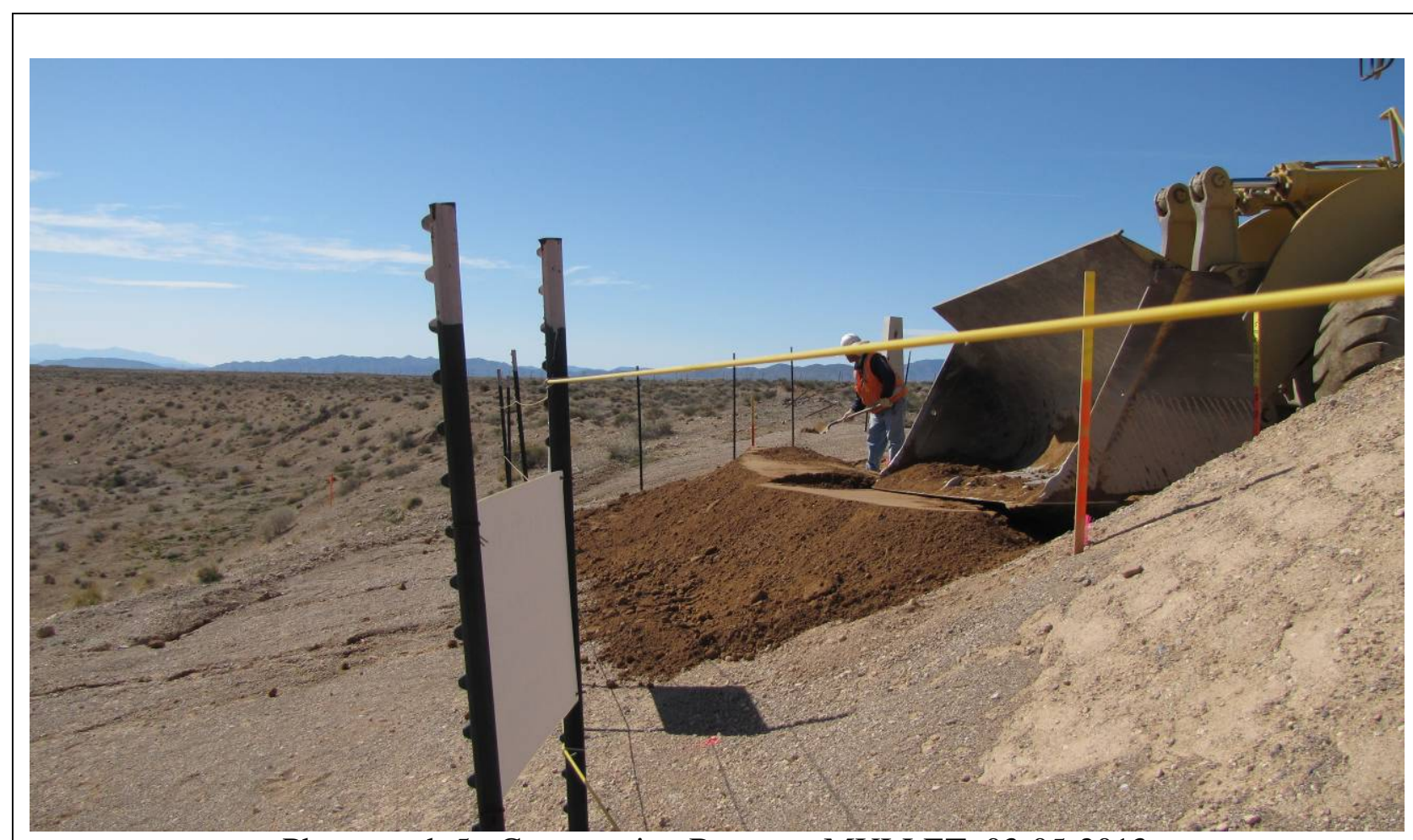

Photograph 5: Constructing Berms at MULLET, 03-05-2013

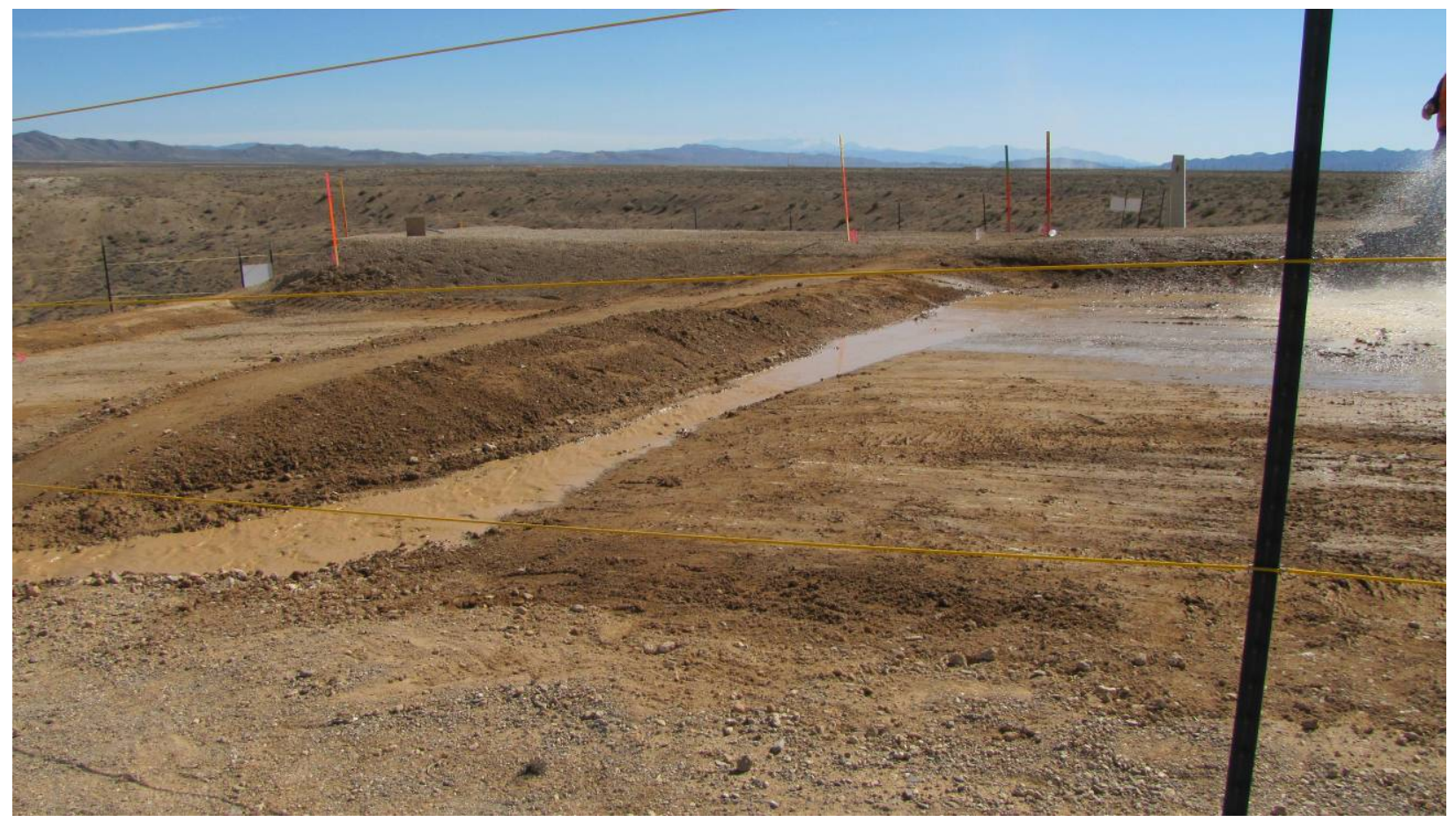

Photograph 6: Flow Testing the Berms at MULLET, 03-05-2013 


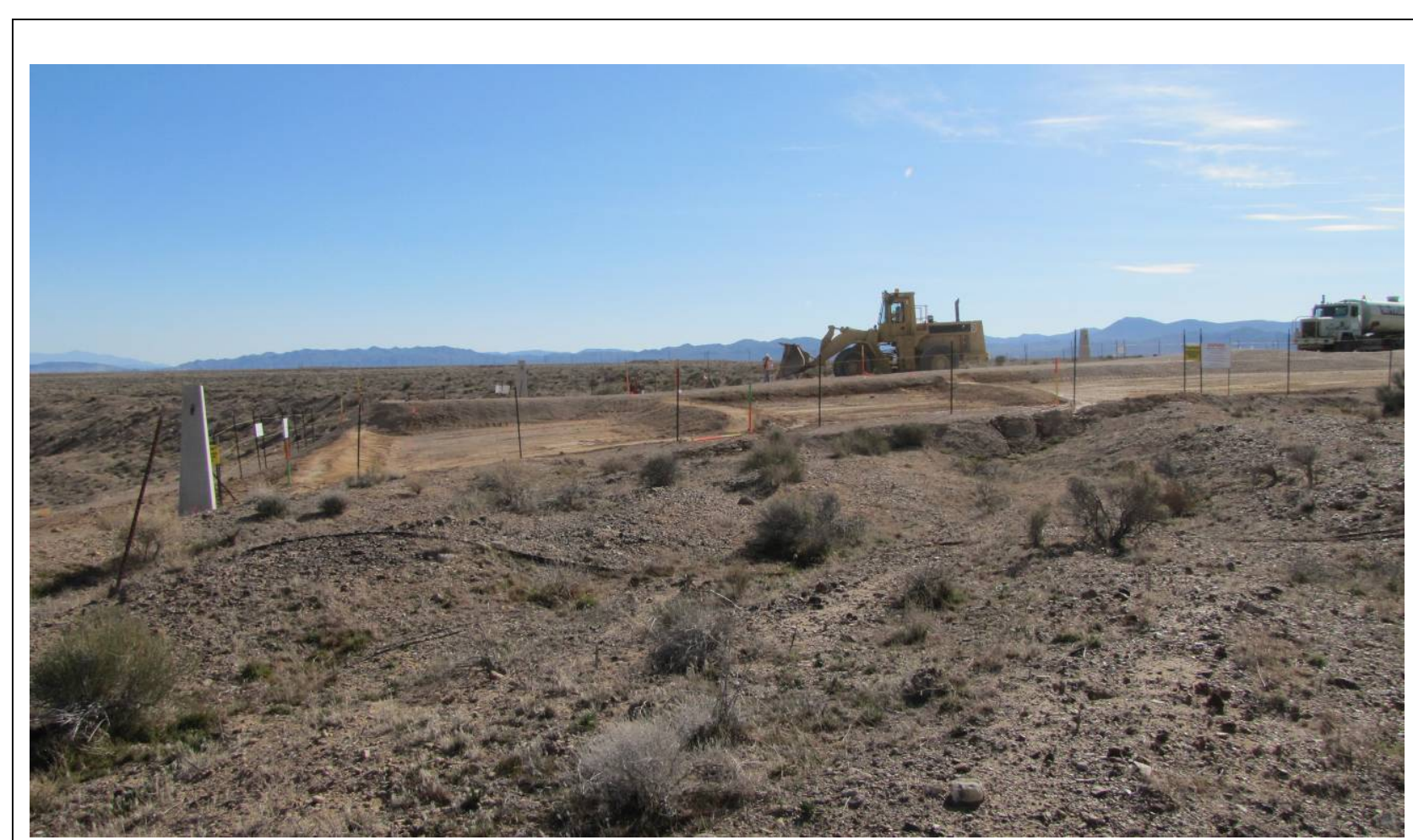

Photograph 7: Constructing Berms at MULLET, 03-05-2013

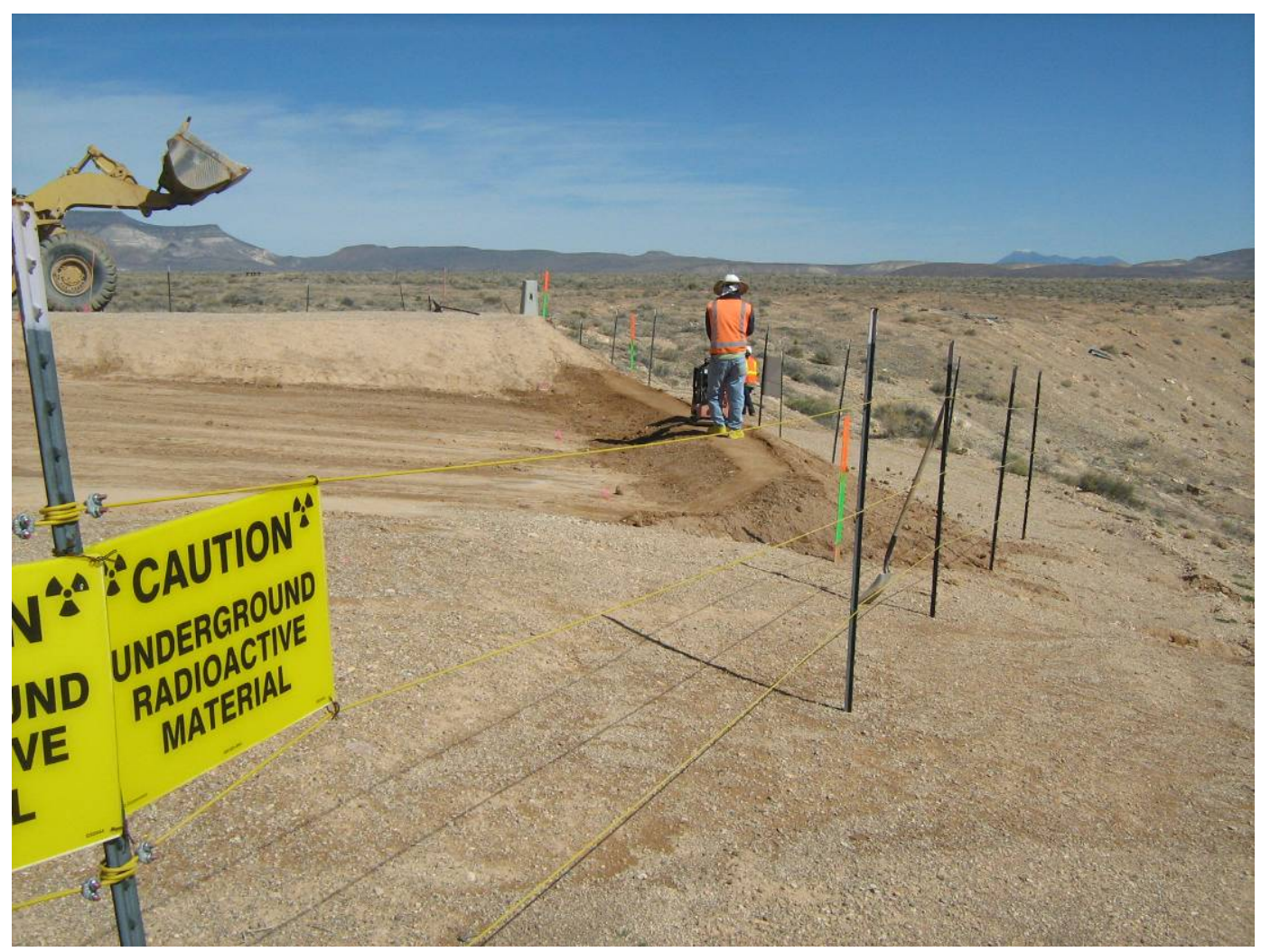

Photograph 8: Constructing Berms at MULLET, 03-05-2013 


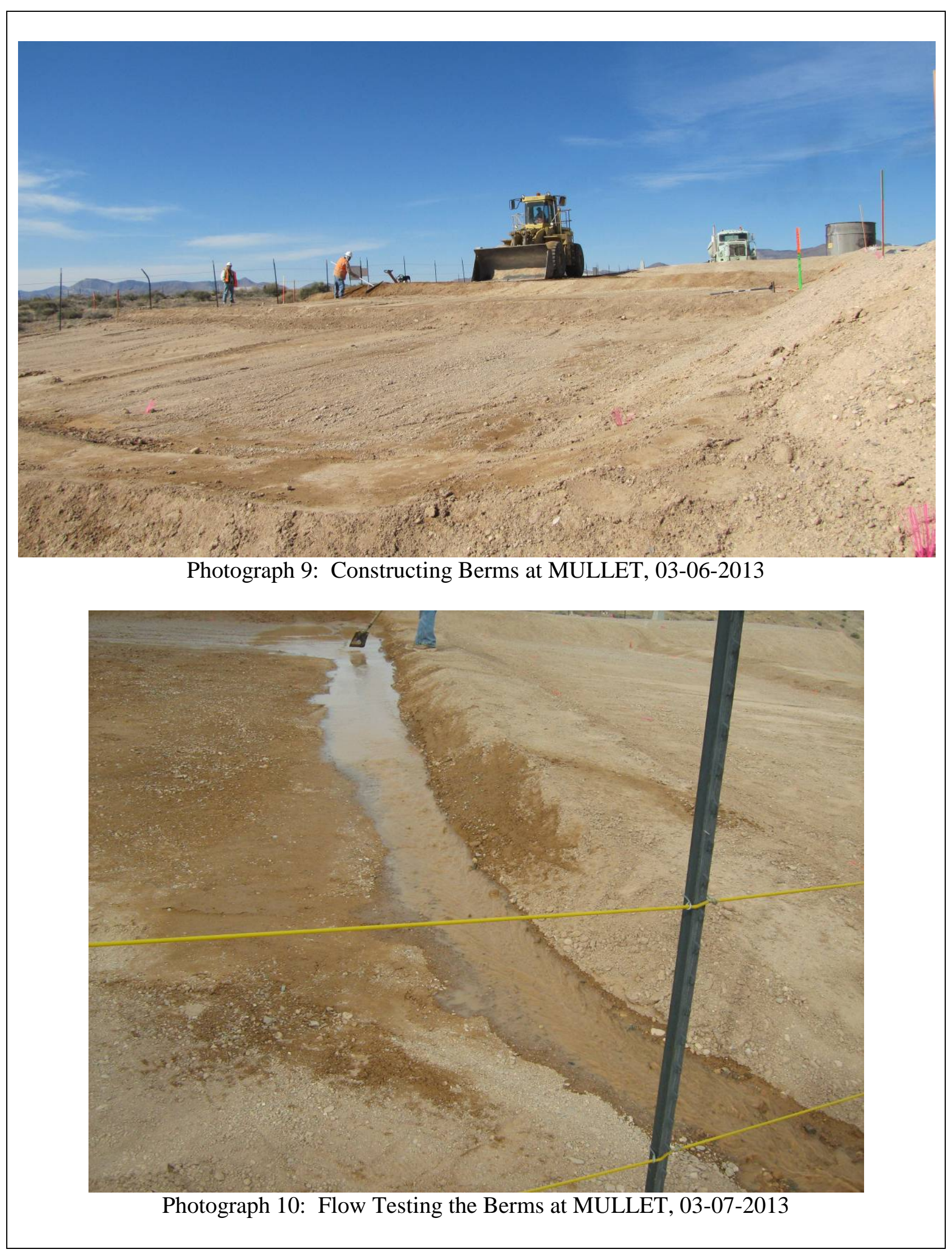




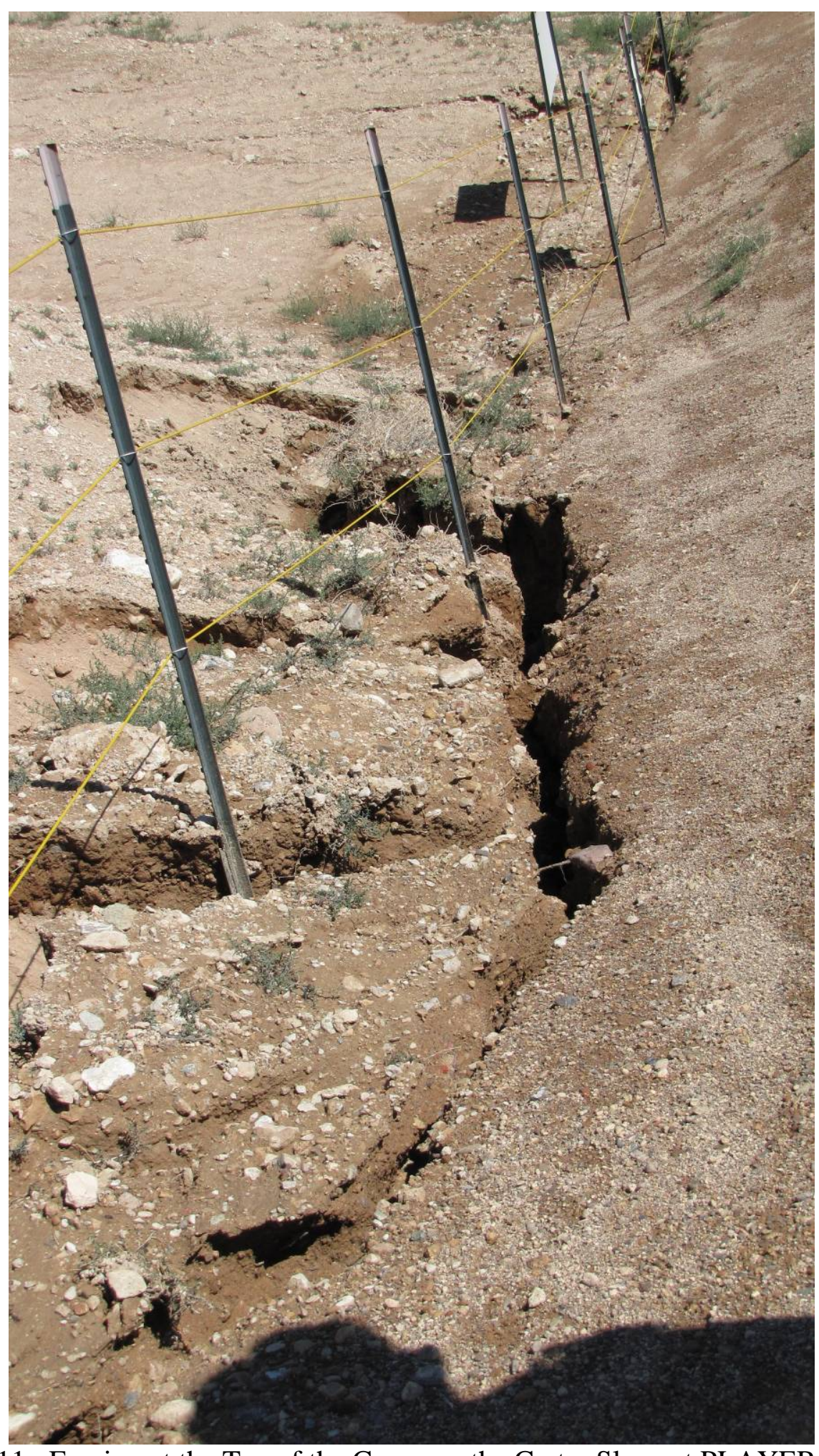

Photograph 11: Erosion at the Toe of the Cover on the Crater Slope at PLAYER, 08-23-2012 


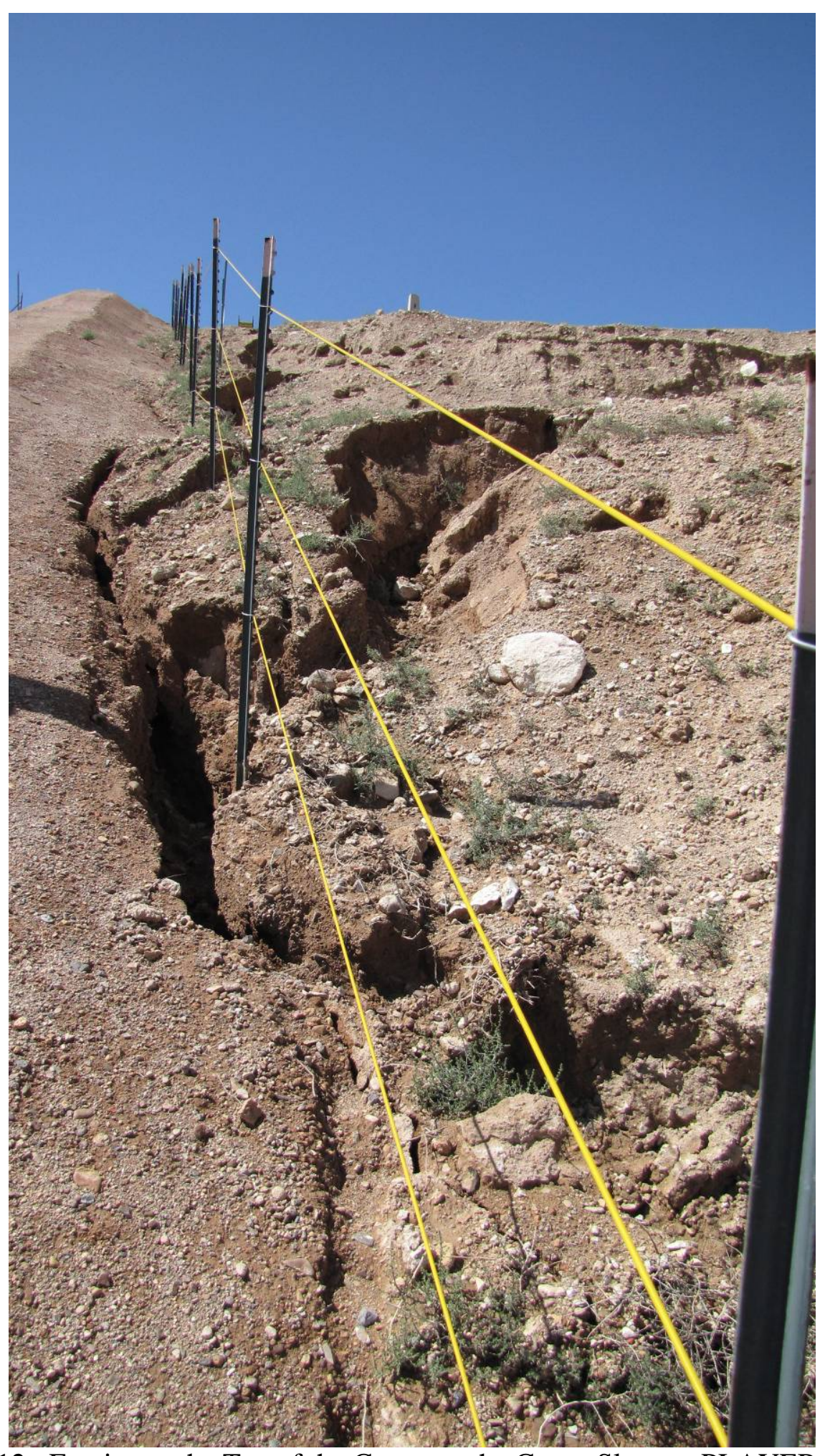

Photograph 12: Erosion at the Toe of the Cover on the Crater Slope at PLAYER, 08-23-2012 


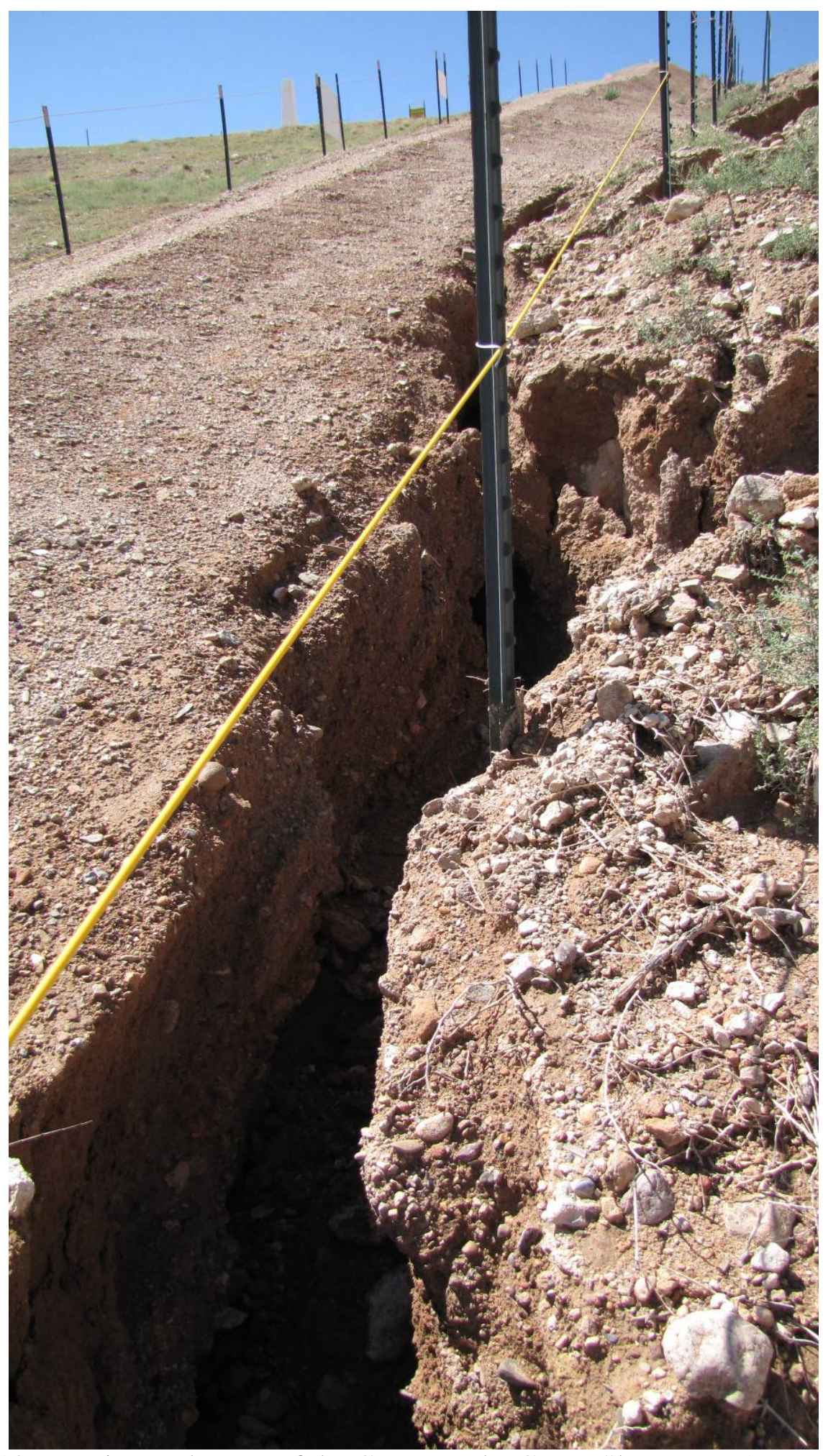

Photograph 13: Erosion at the Toe of the Cover on the Crater Slope at PLAYER, 08-23-2012 


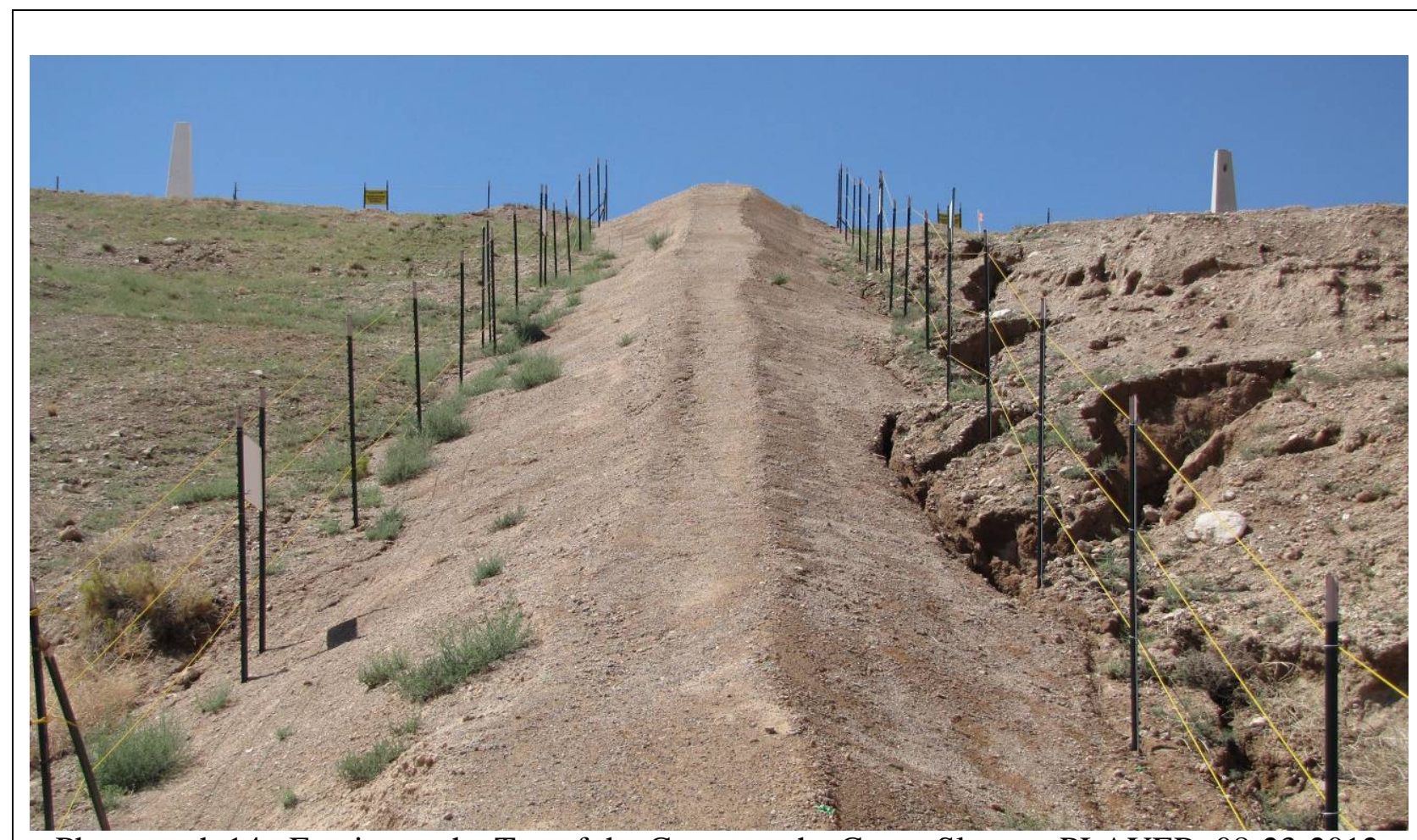

Photograph 14: Erosion at the Toe of the Cover on the Crater Slope at PLAYER, 08-23-2012

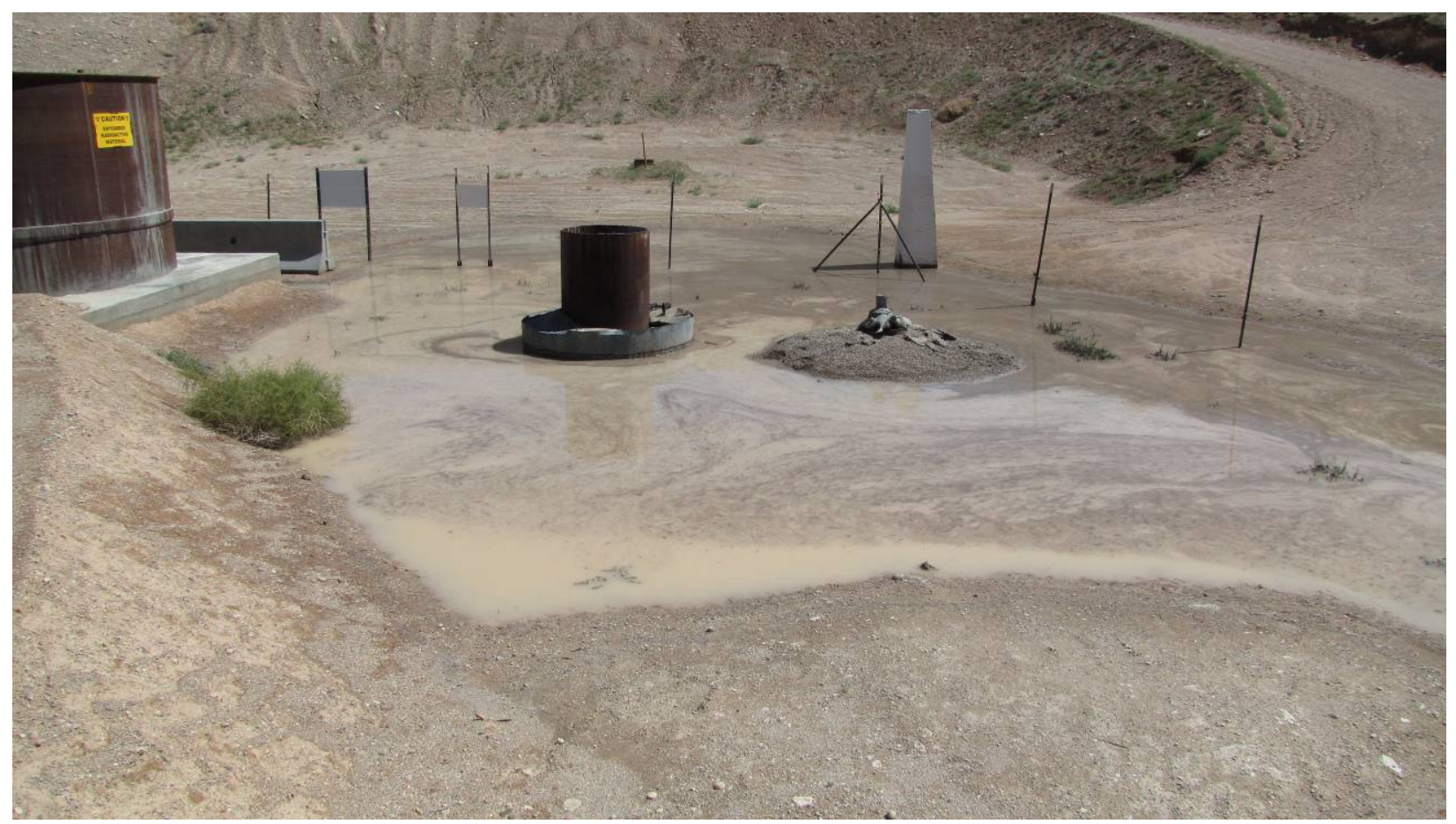

Photograph 15: Standing Water at the Bottom of the Crater at PLAYER, 08-23-2012 


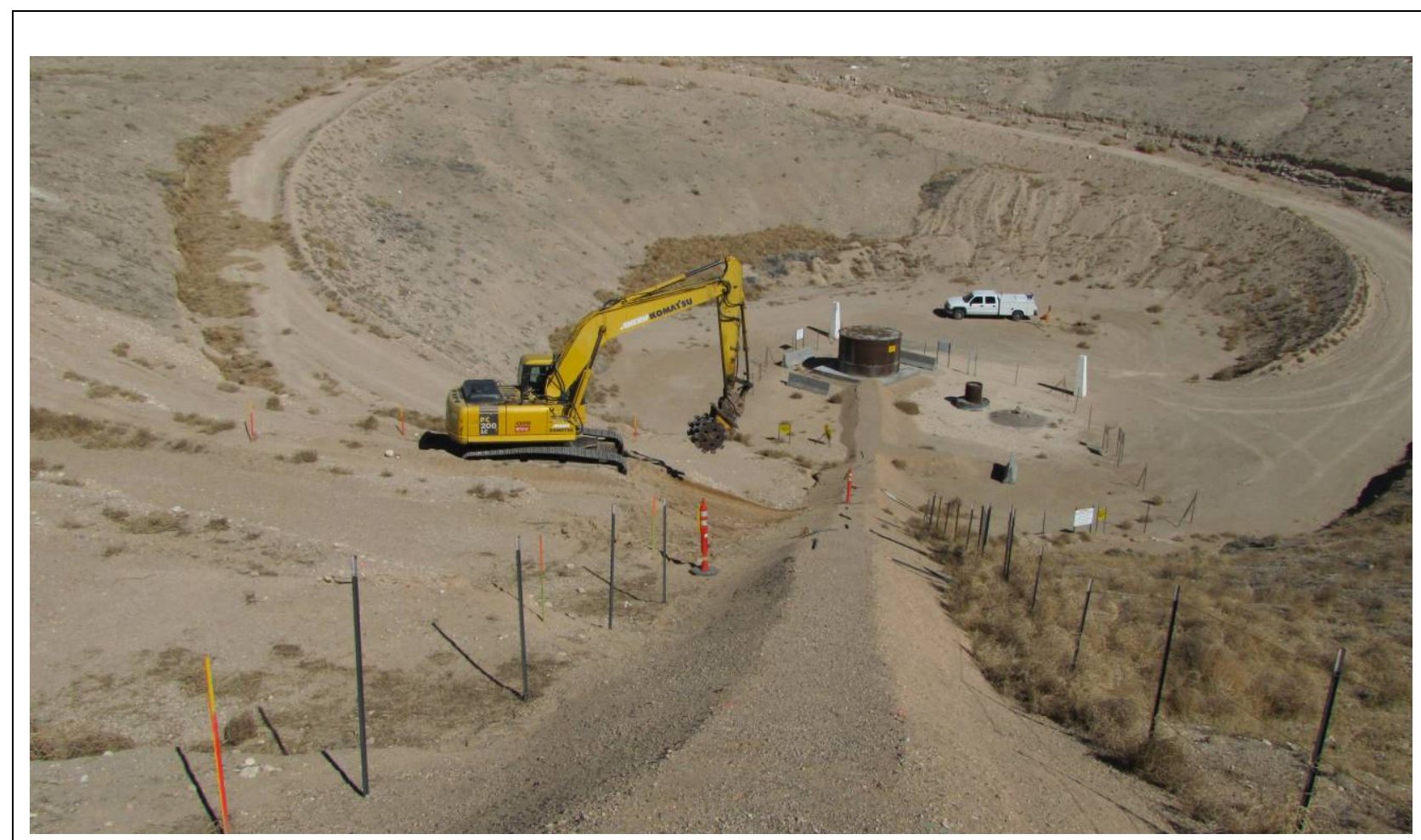

Photograph 16: Repairing Erosion at PLAYER, 02-13-2013

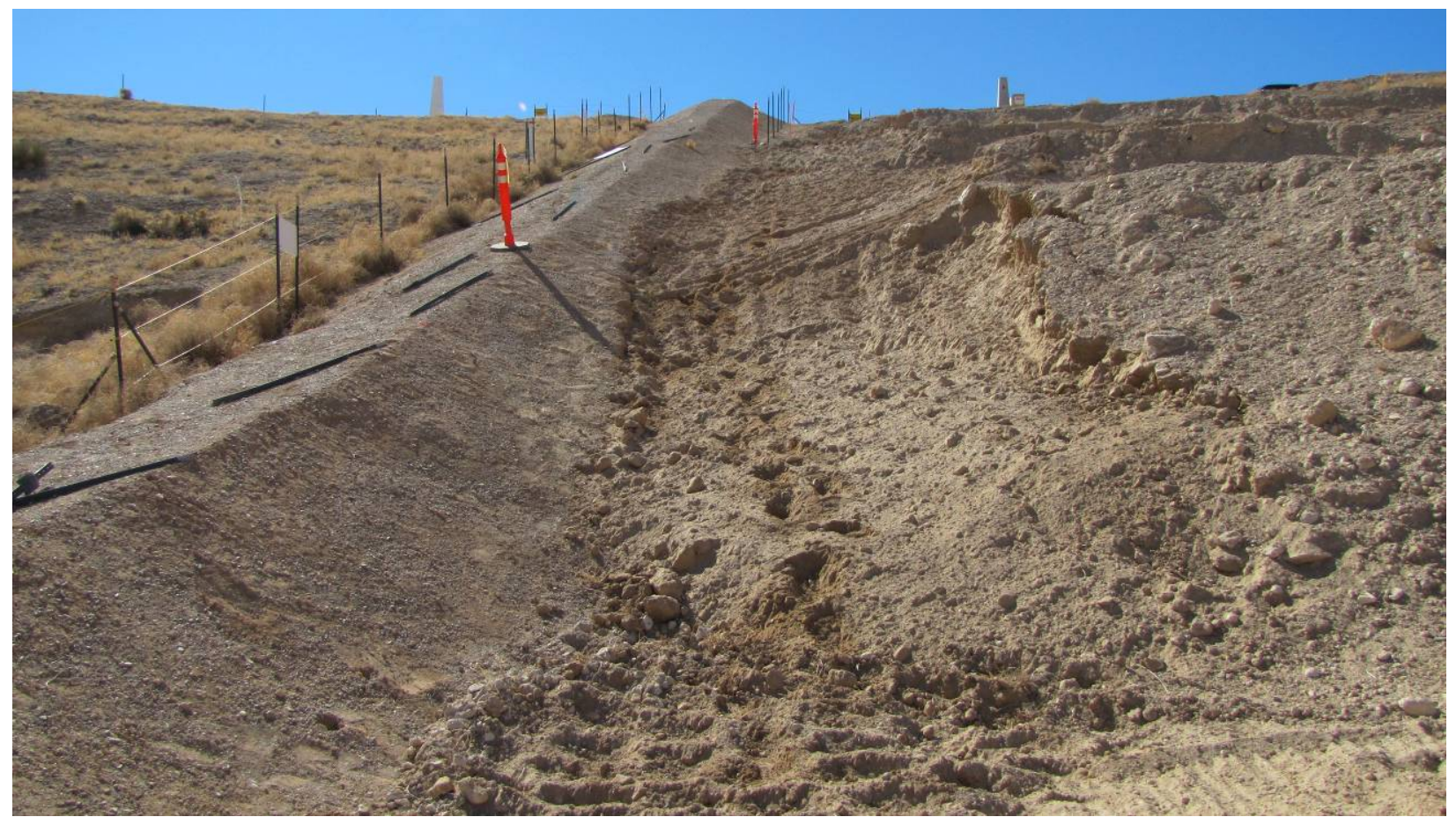

Photograph 17: Repairing Erosion at PLAYER, 02-13-2013 


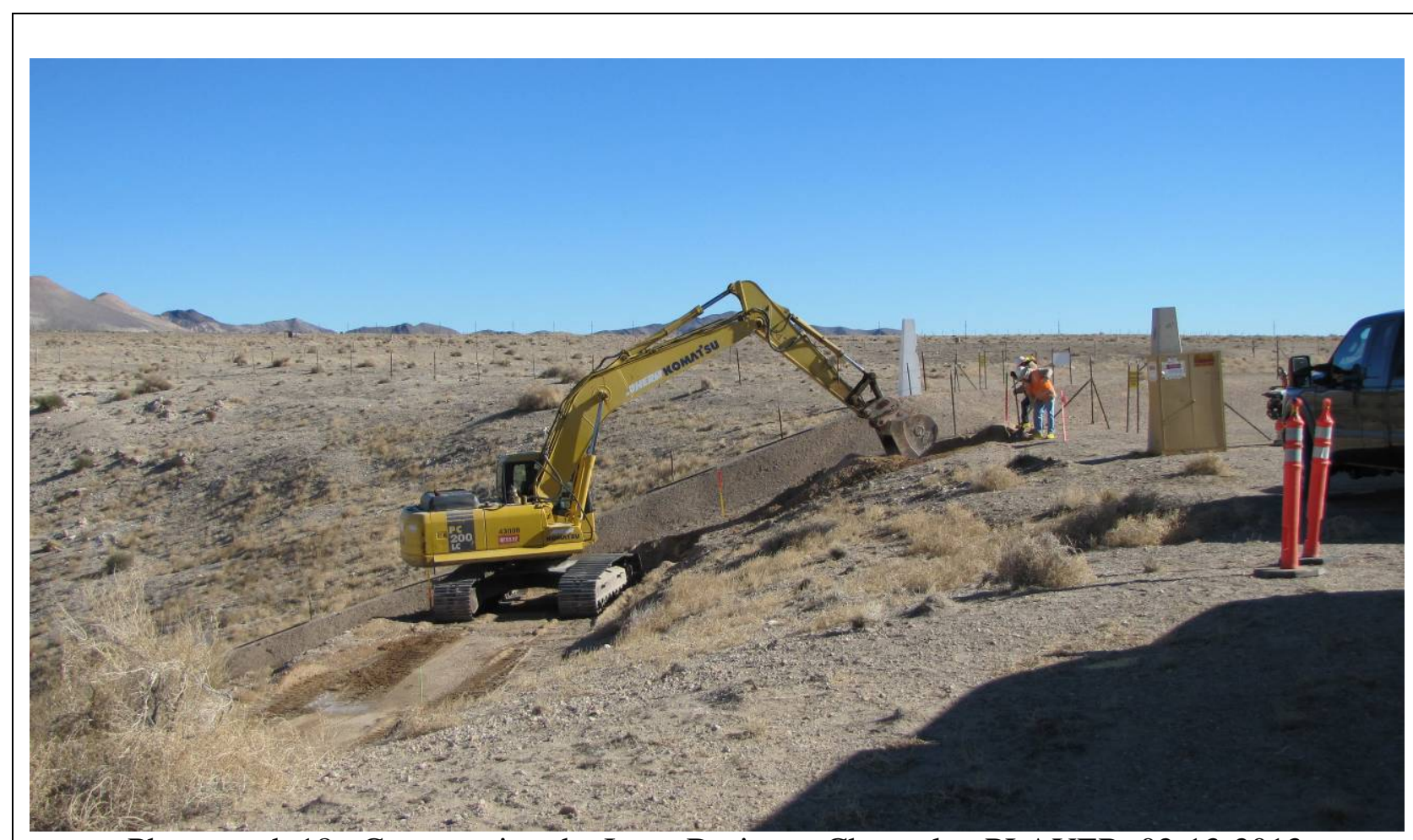

Photograph 18: Constructing the Inner Drainage Channel at PLAYER, 02-13-2013

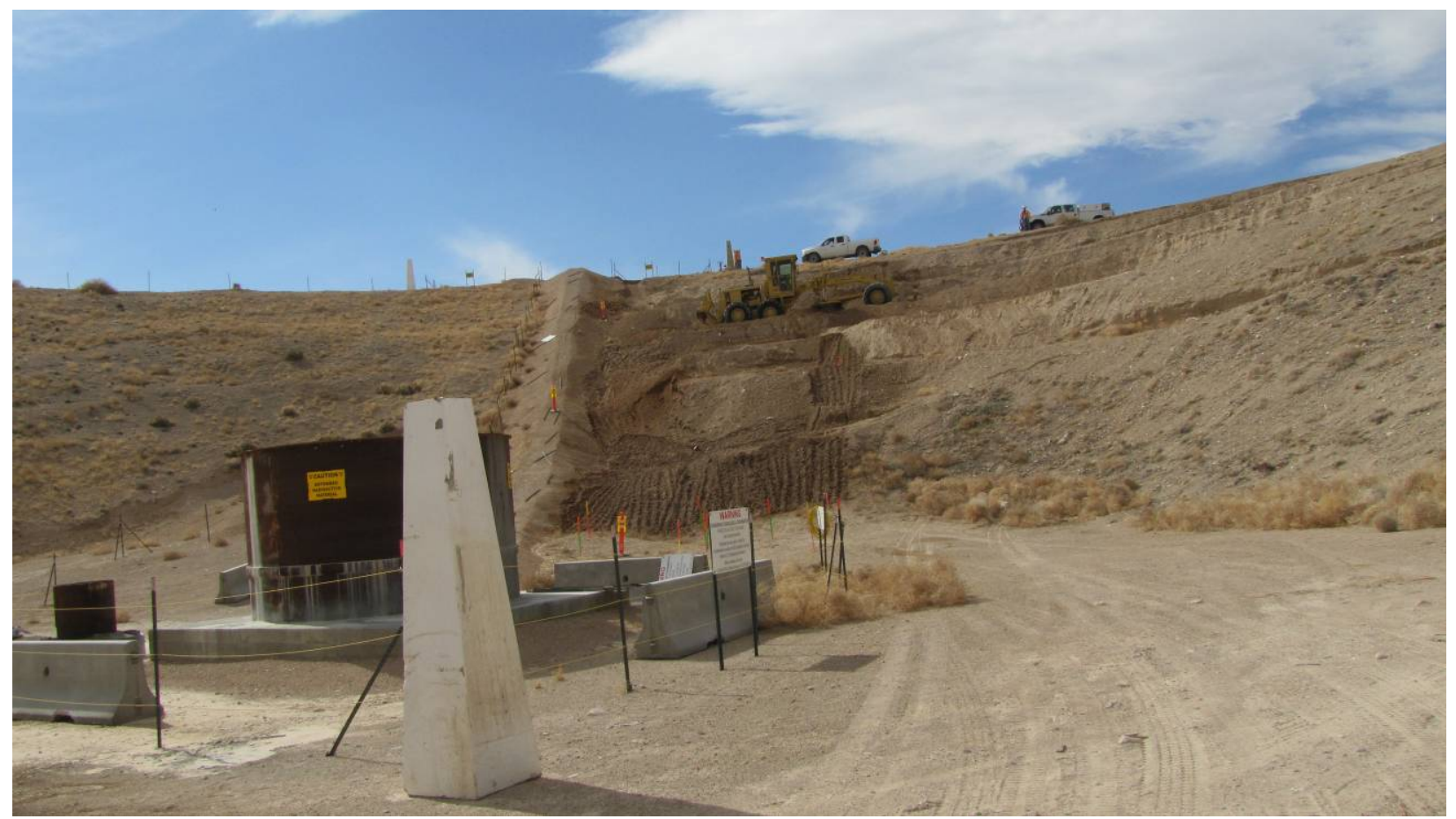

Photograph 19: Sloping and Compacting the Benches at PLAYER, 02-19-2013 


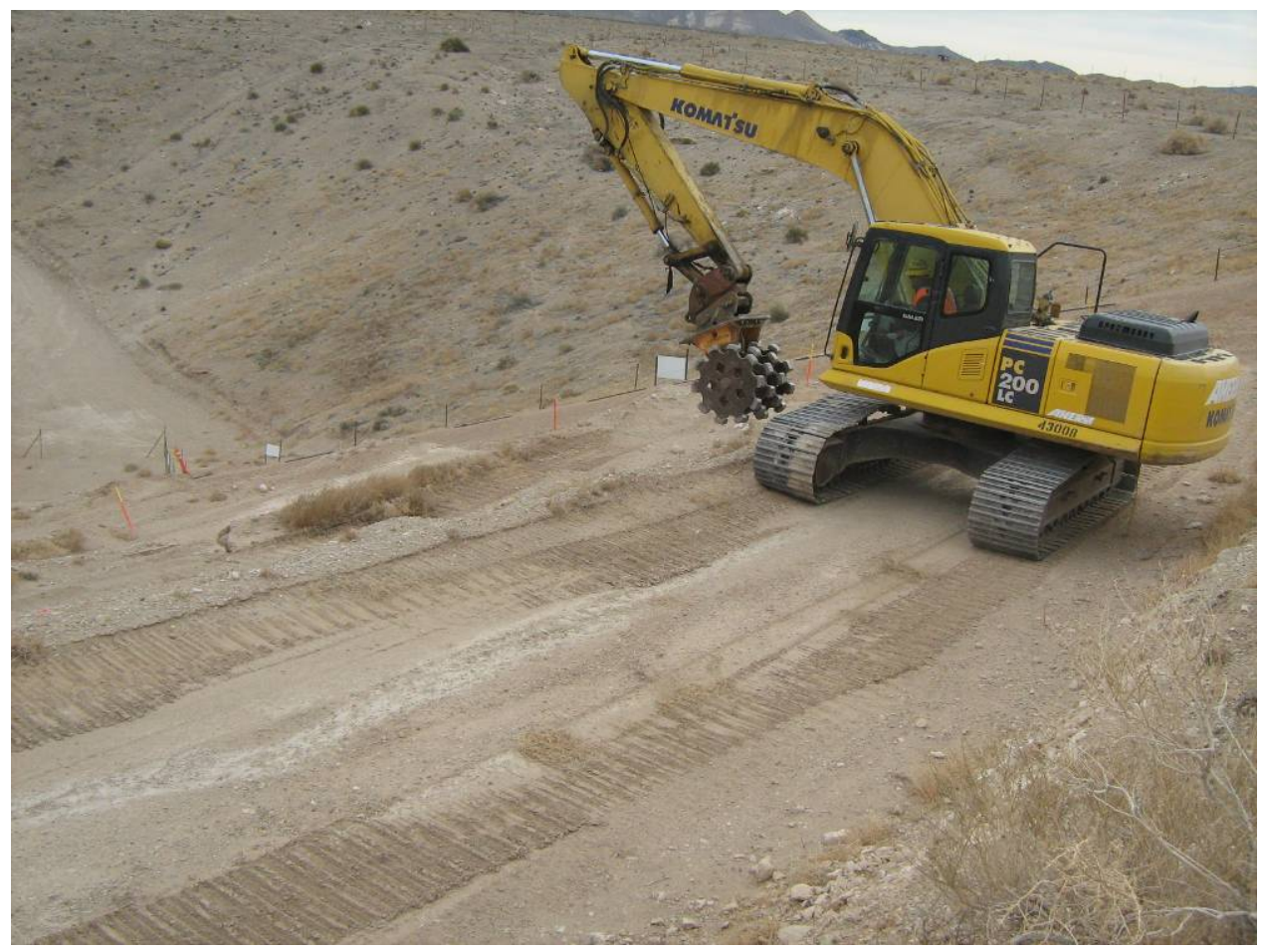

Photograph 20: Compacting the Benches at PLAYER, 02-19-2013

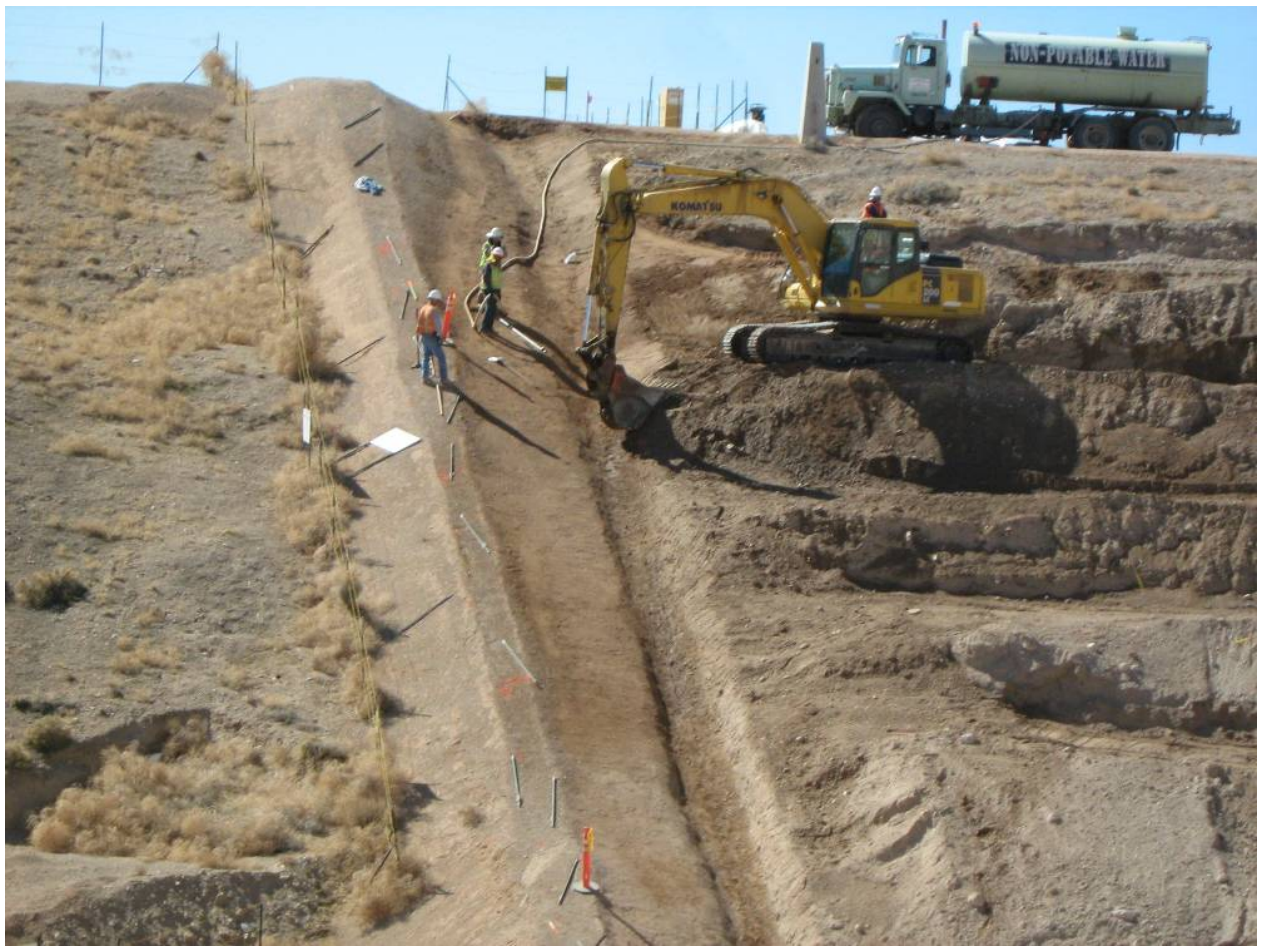

Photograph 21: Constructing the Inner Drainage Channel at PLAYER, 02-25-2013 


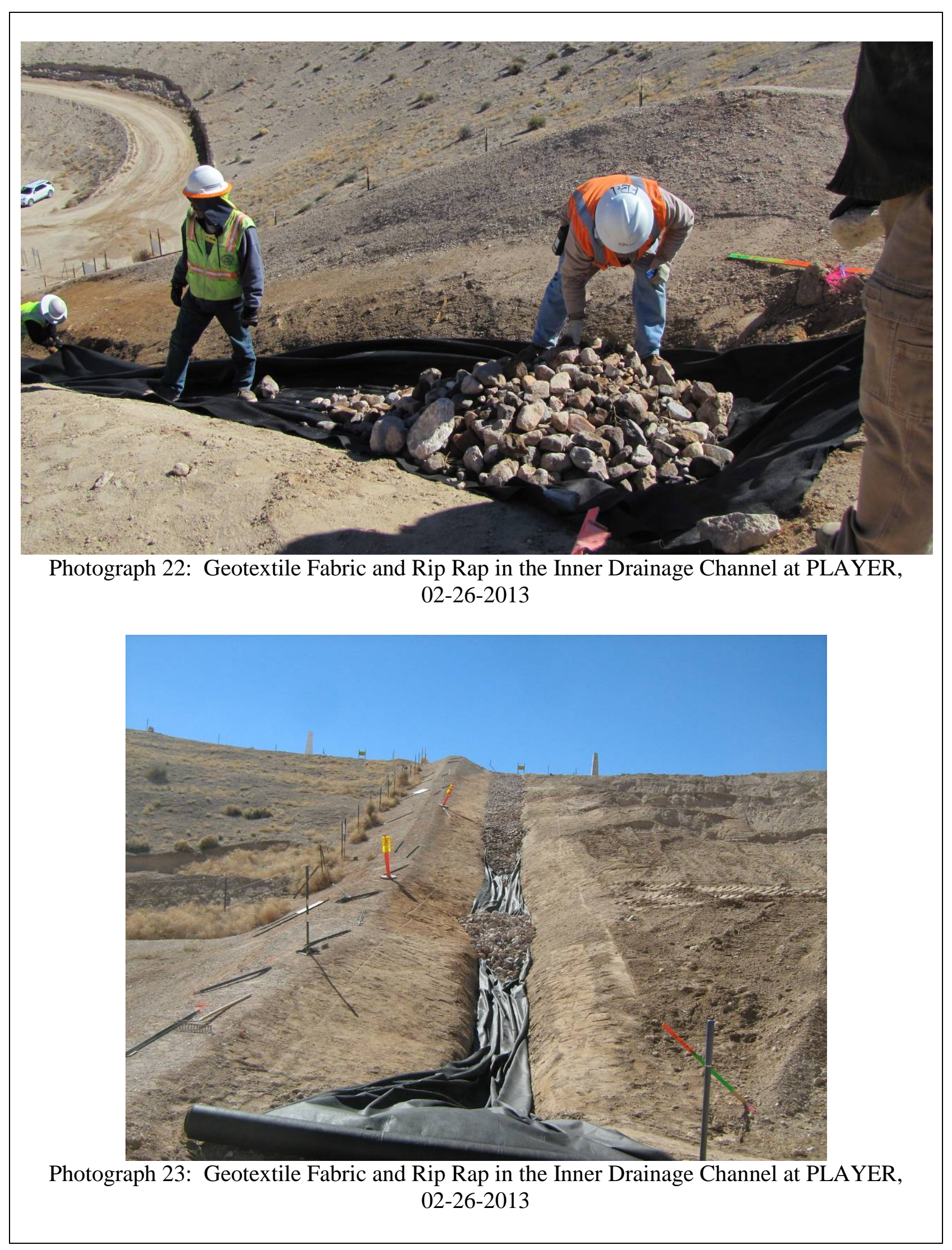




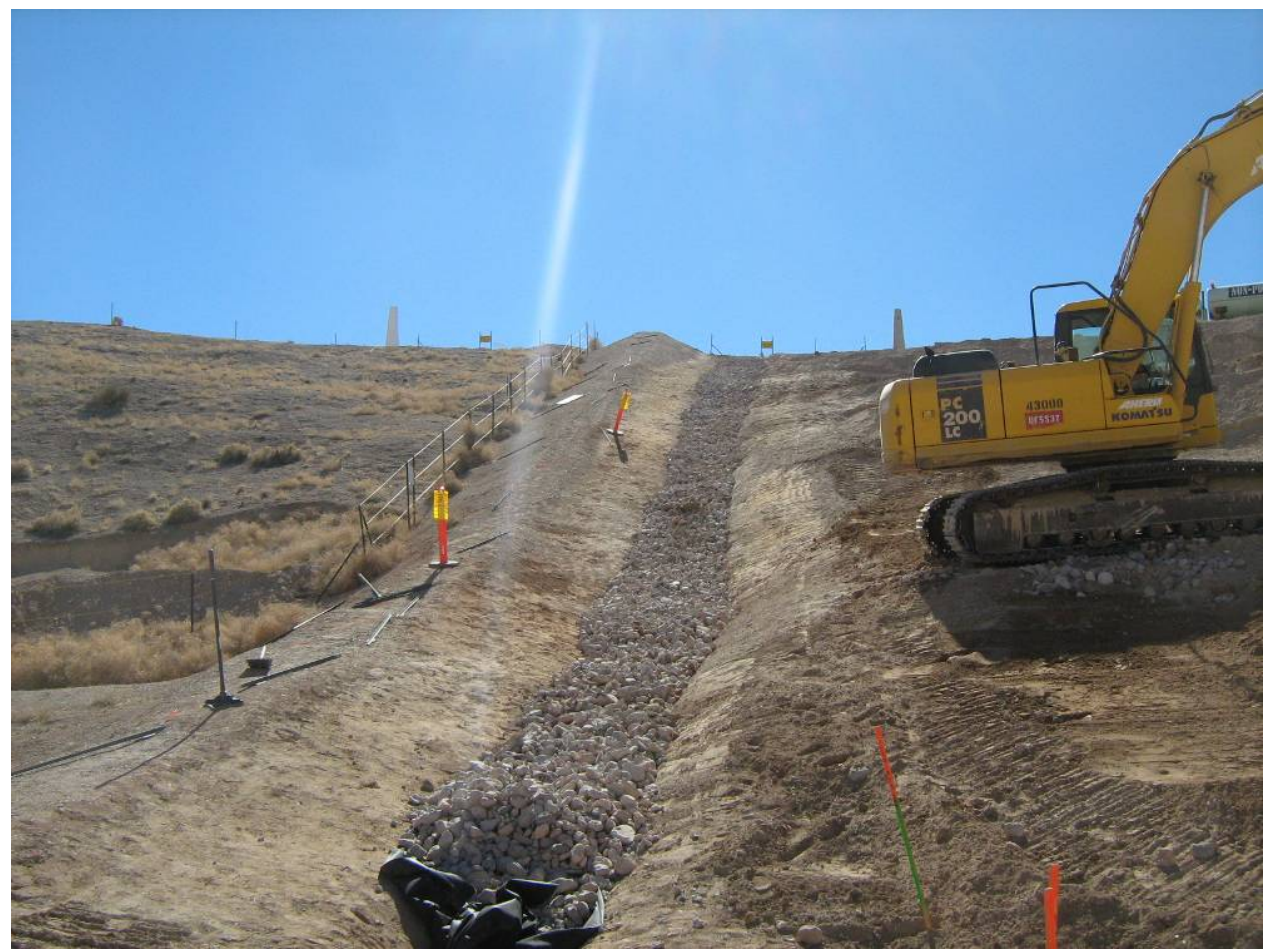

Photograph 24: Geotextile Fabric and Rip Rap in the Inner Drainage Channel at PLAYER, 02-26-2013

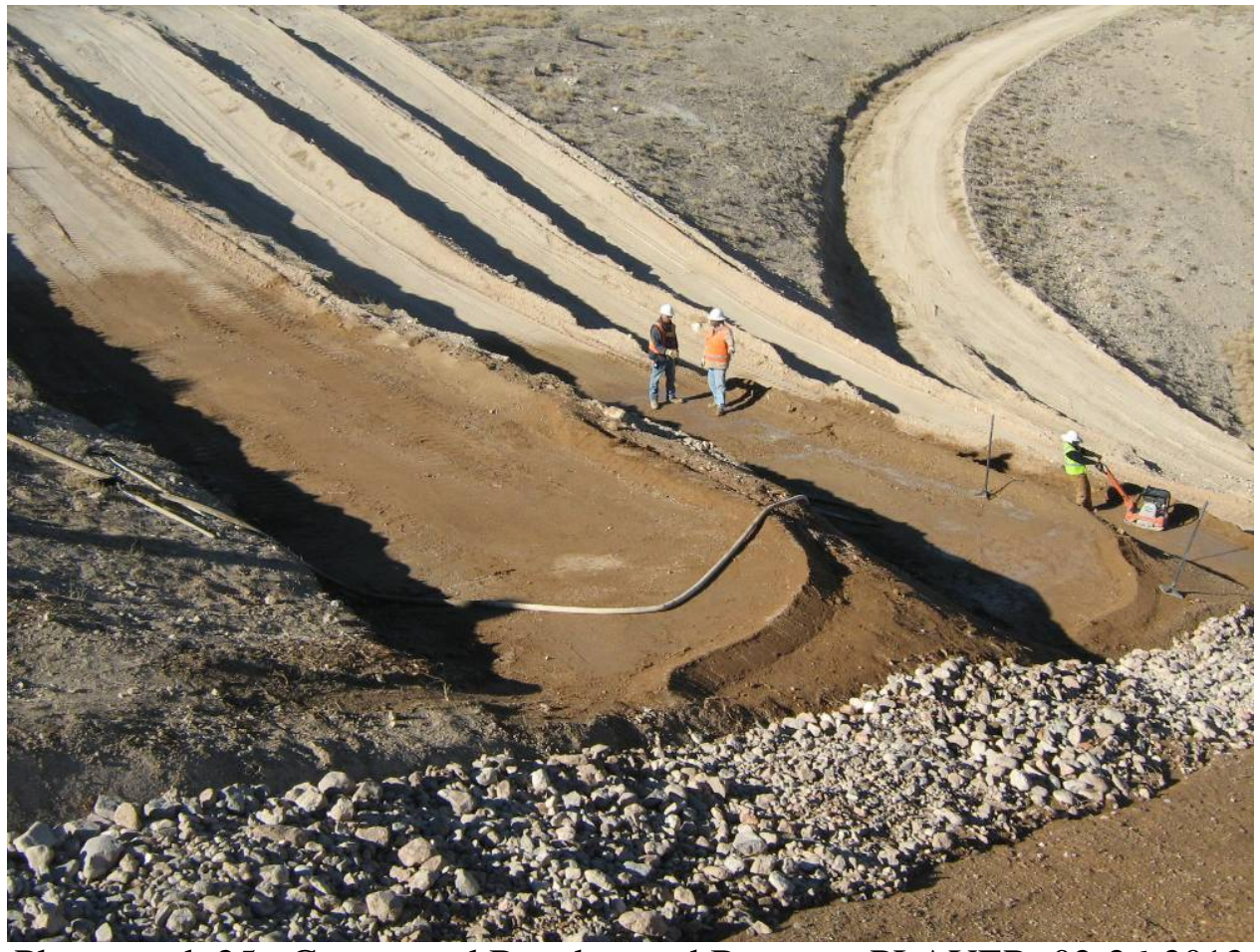

Photograph 25: Compacted Benches and Berms at PLAYER, 02-26-2013 


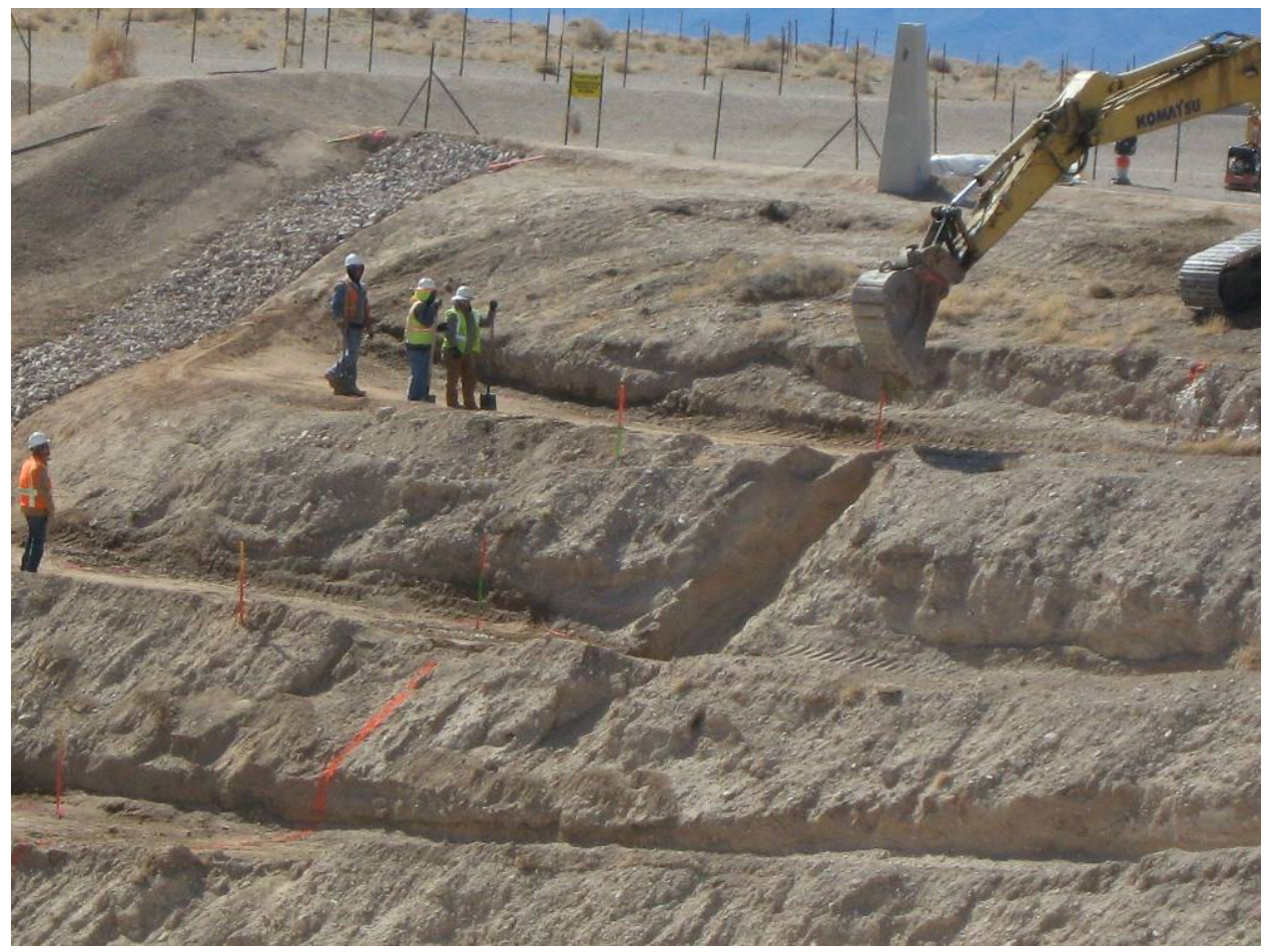

Photograph 26: Constructing the Outer Drainage Channel at PLAYER, 02-27-2013

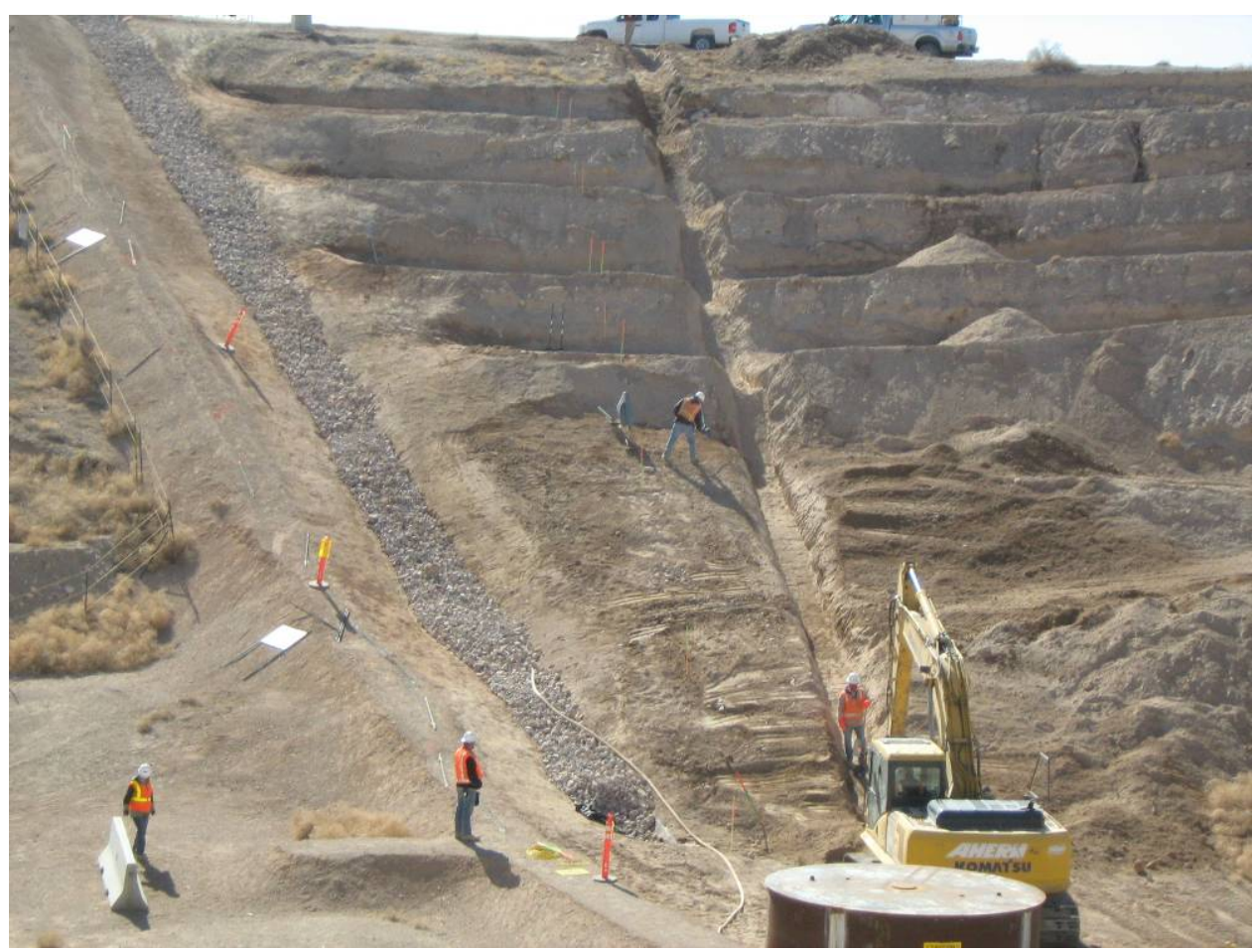

Photograph 27: Constructing the Outer Drainage Channel at PLAYER, 02-27-2013 


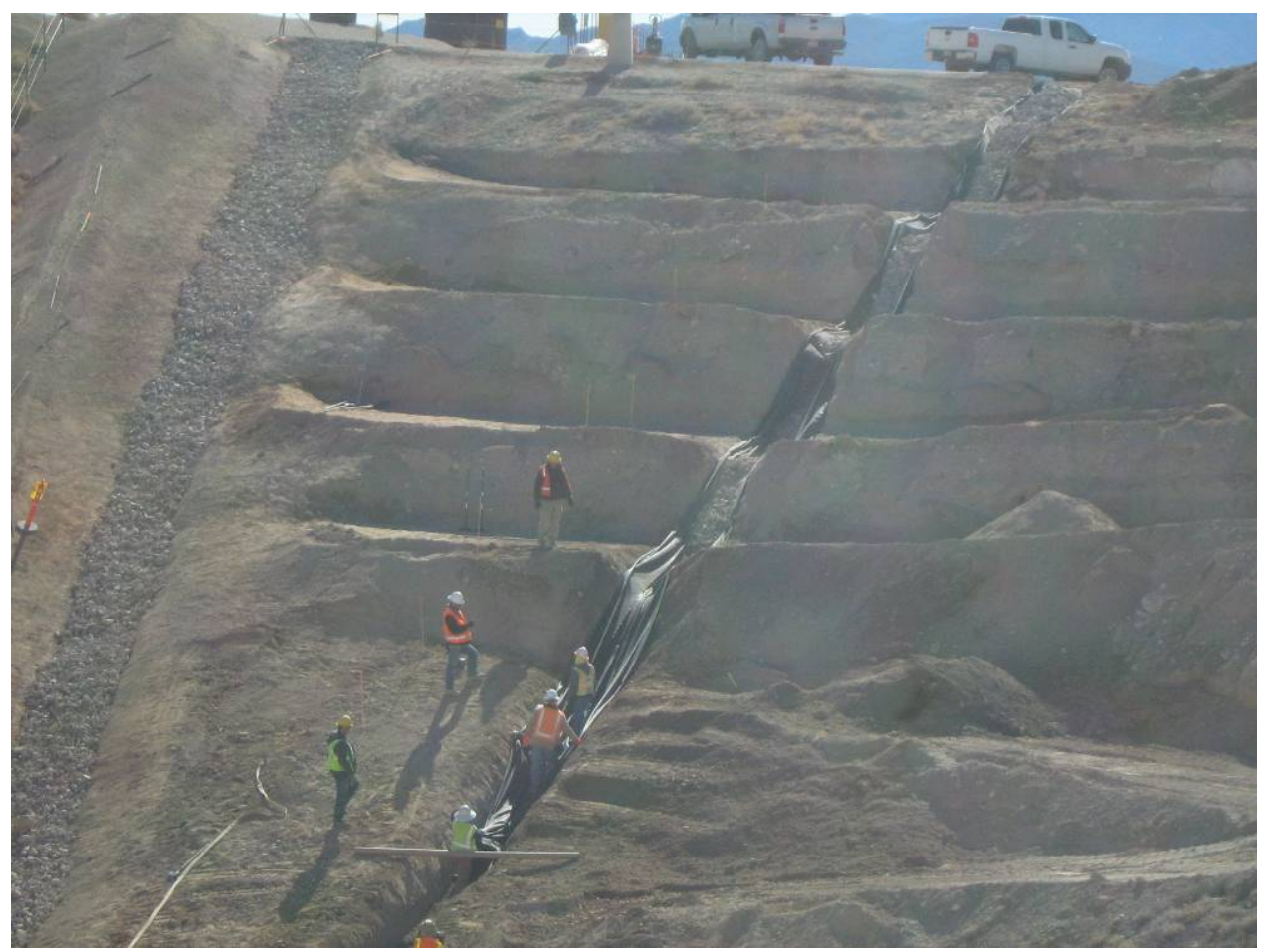

Photograph 28: Geotextile Fabric and Rip Rap in the Outer Drainage Channel at PLAYER, 02-27-2013

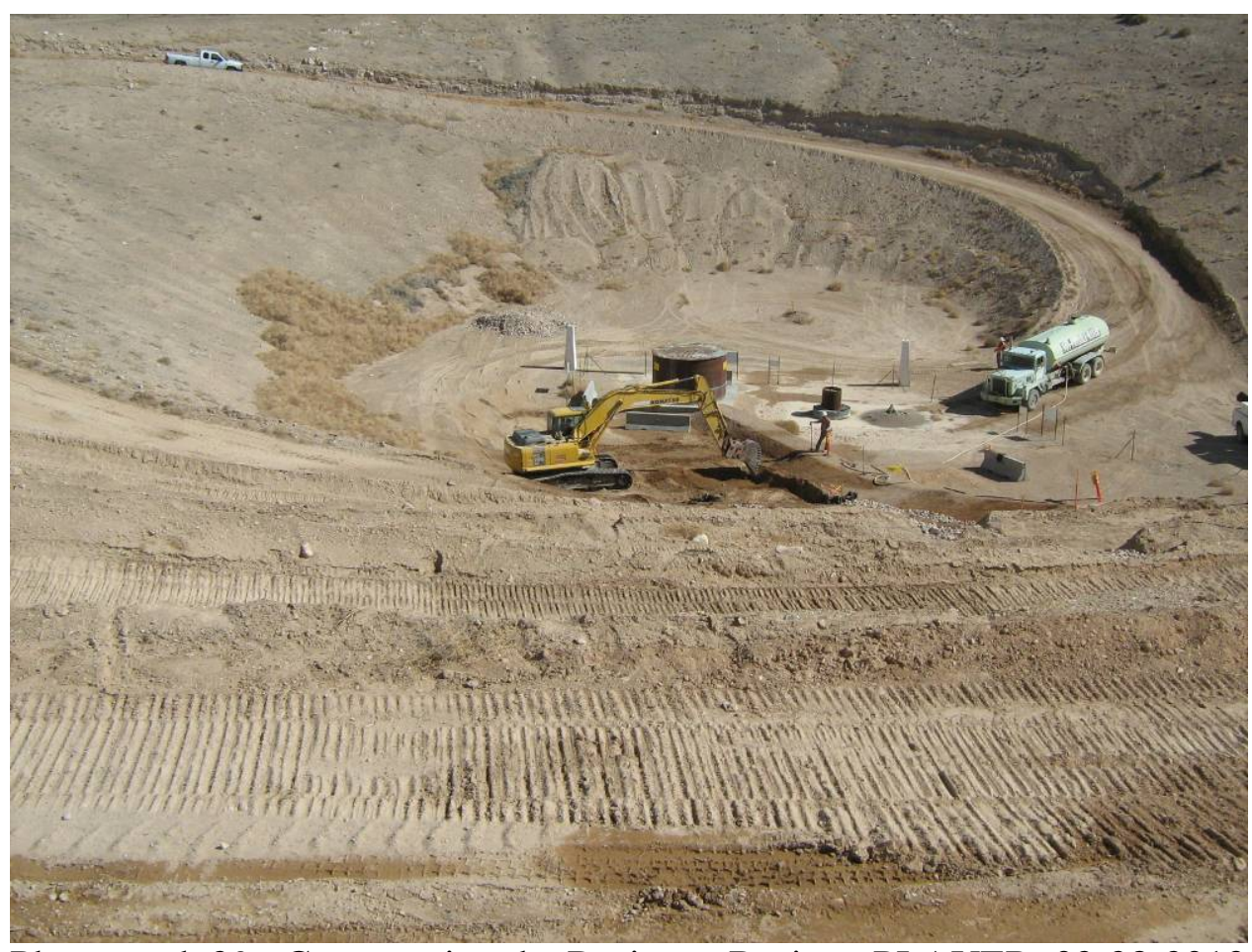

Photograph 29: Constructing the Drainage Basin at PLAYER, 02-28-2013 


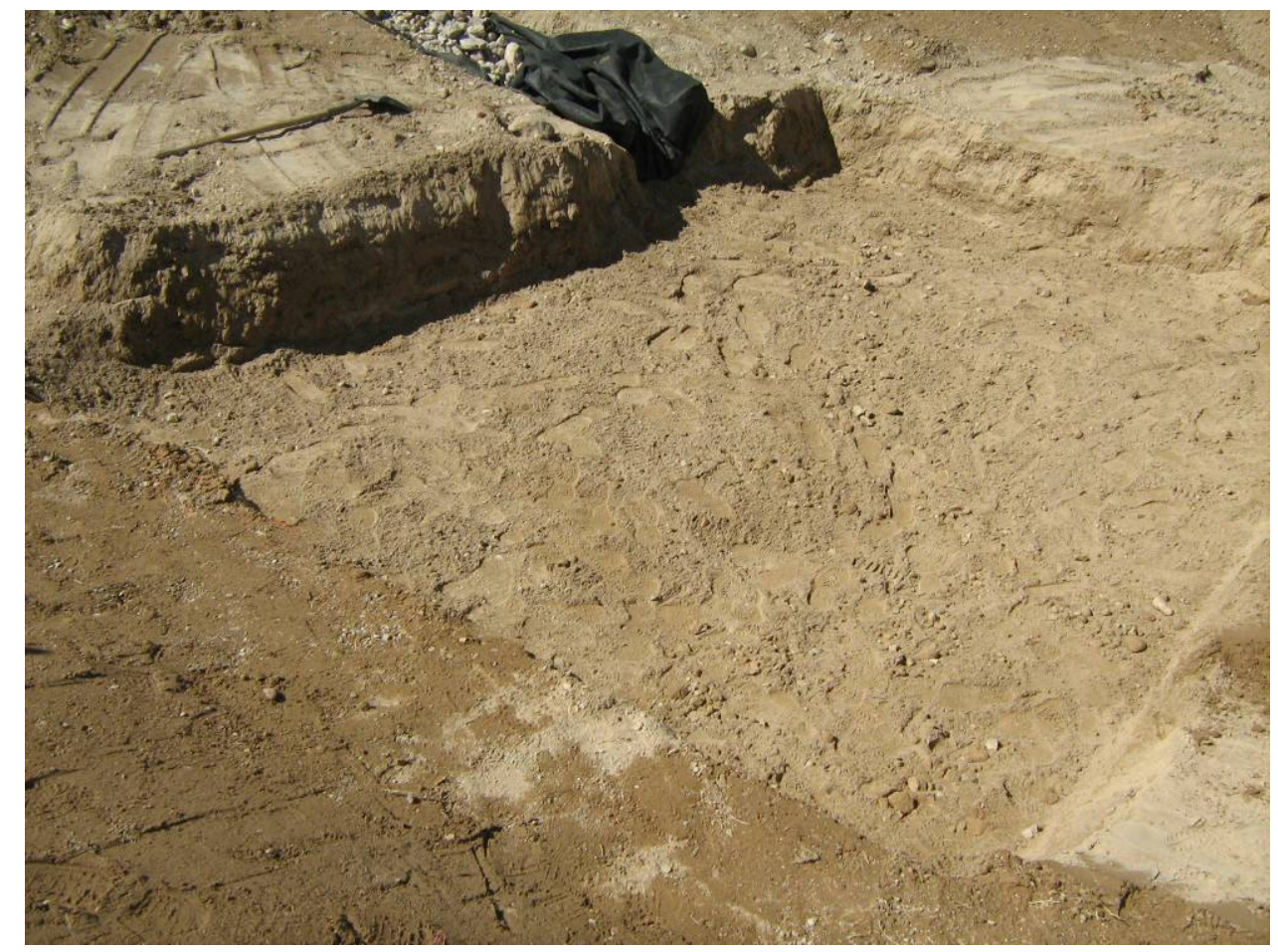

Photograph 30: Drainage Basin at PLAYER, 02-28-2013

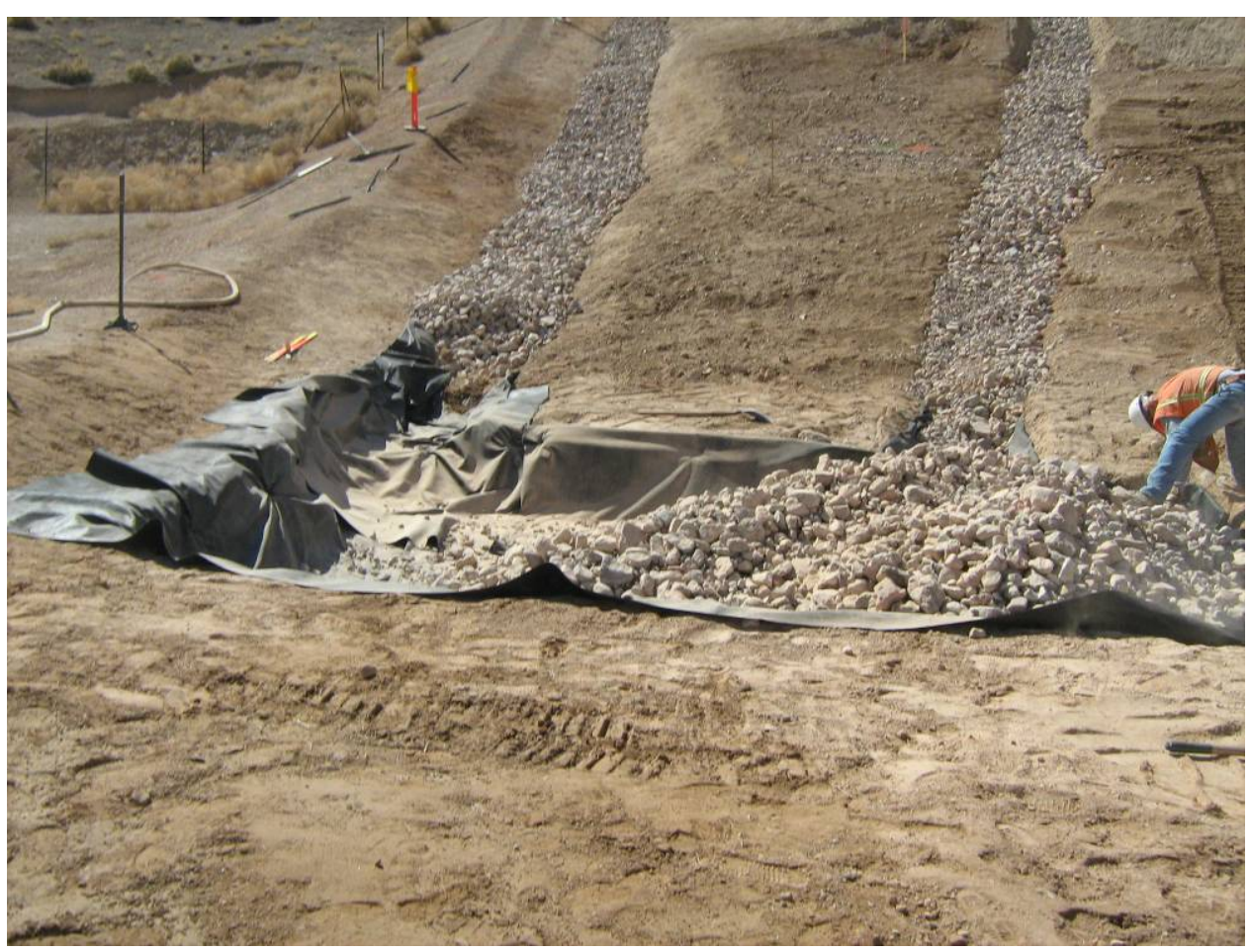

Photograph 31: Geotextile Fabric and Rip Rap in the Drainage Basin at PLAYER, 02-28-2013 


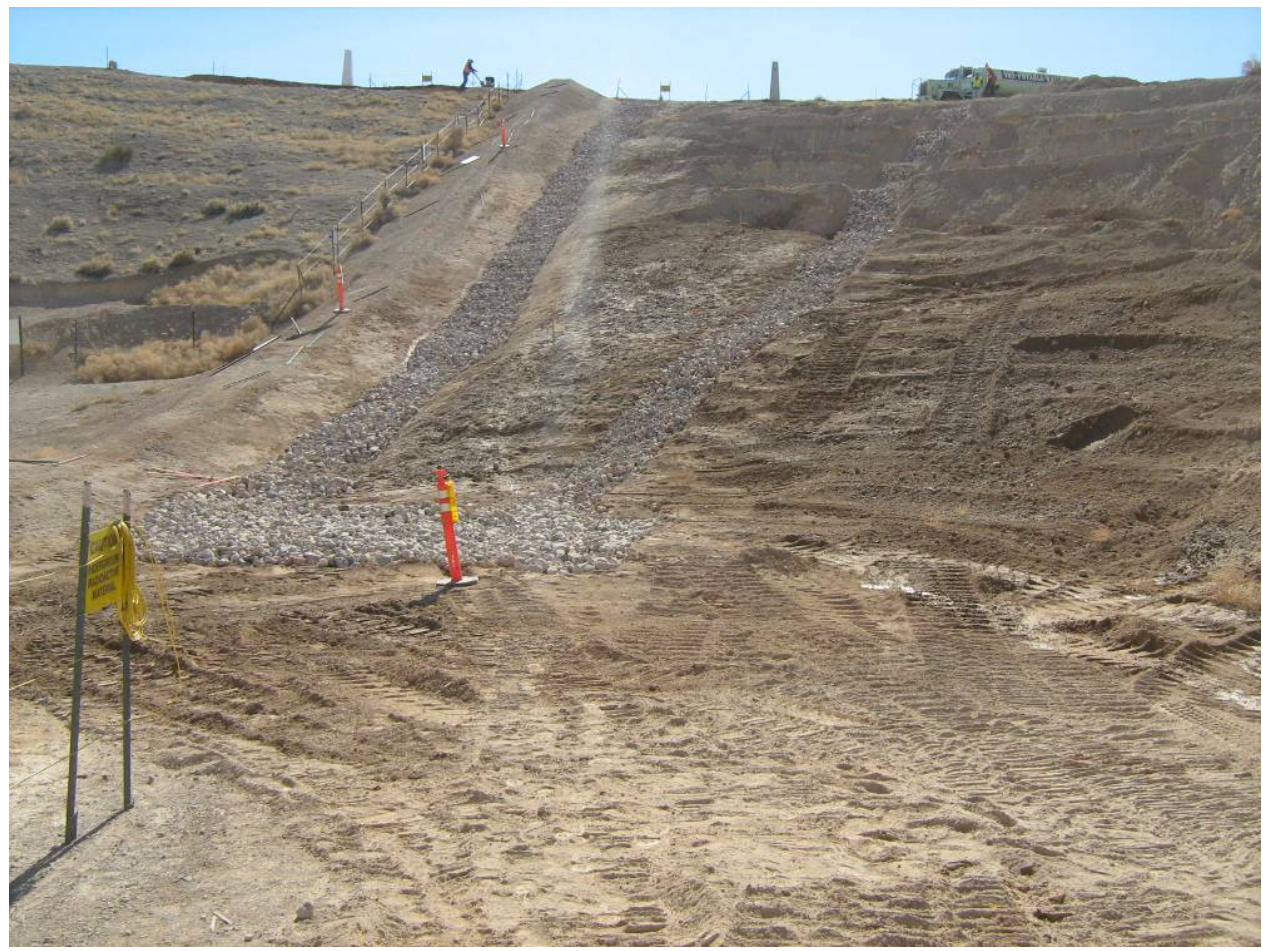

Photograph 32: Completed Drainage Channels and Basin at PLAYER, 02-28-2013

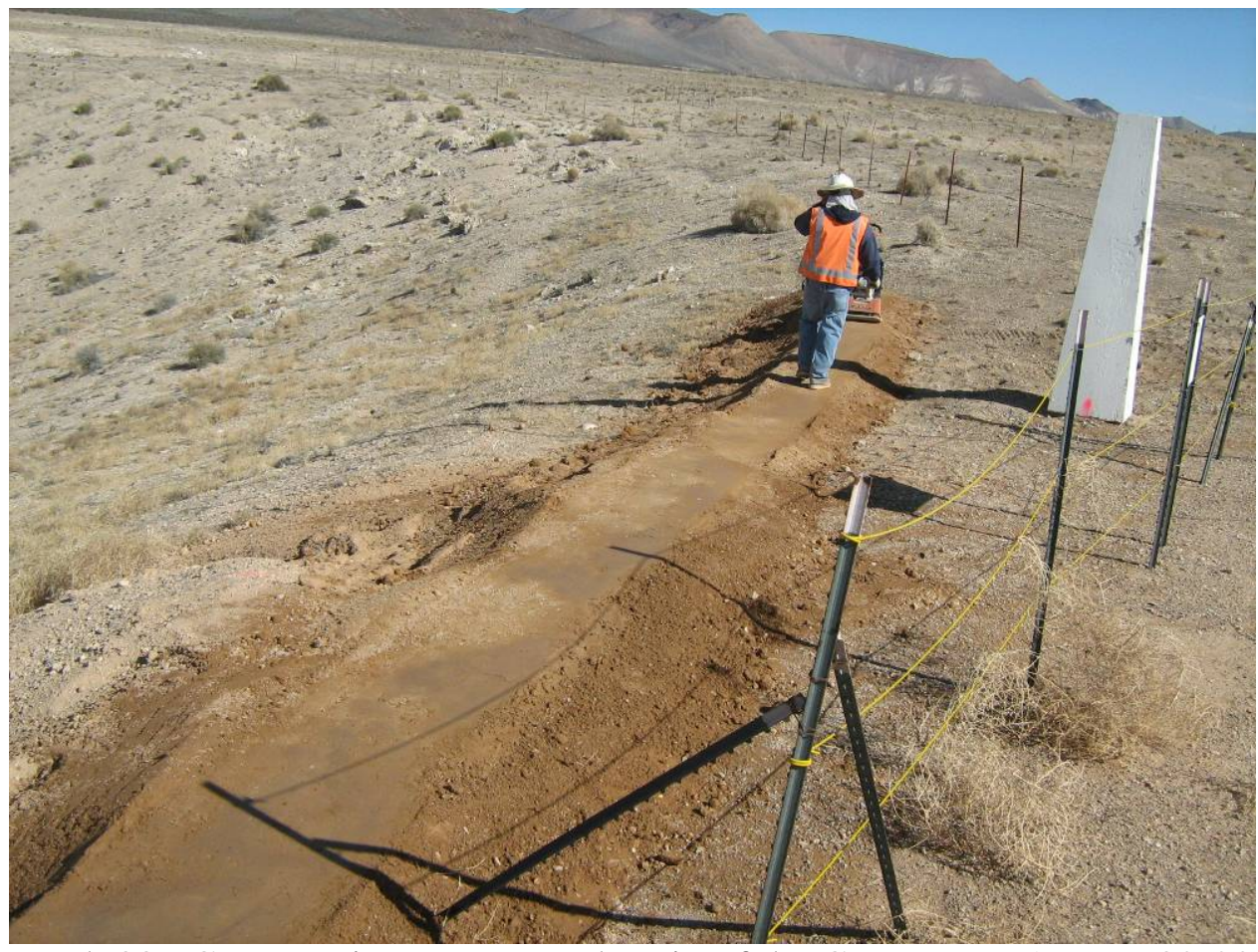

Photograph 33: Constructing Berms on the Lip of the Crater at PLAYER, 02-28-2013 


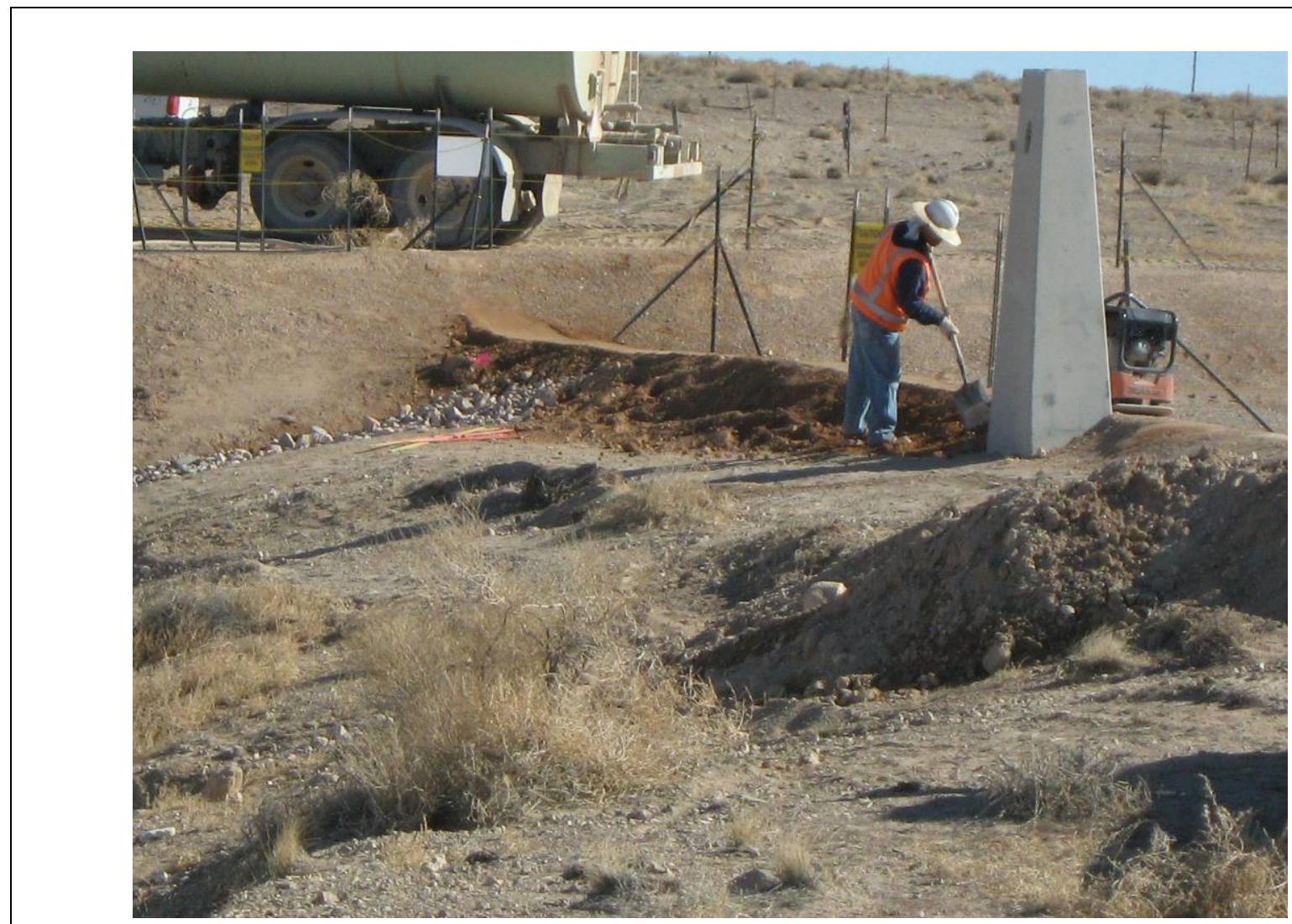

Photograph 34: Constructing Berms on the Lip of the Crater at PLAYER, 02-28-2013

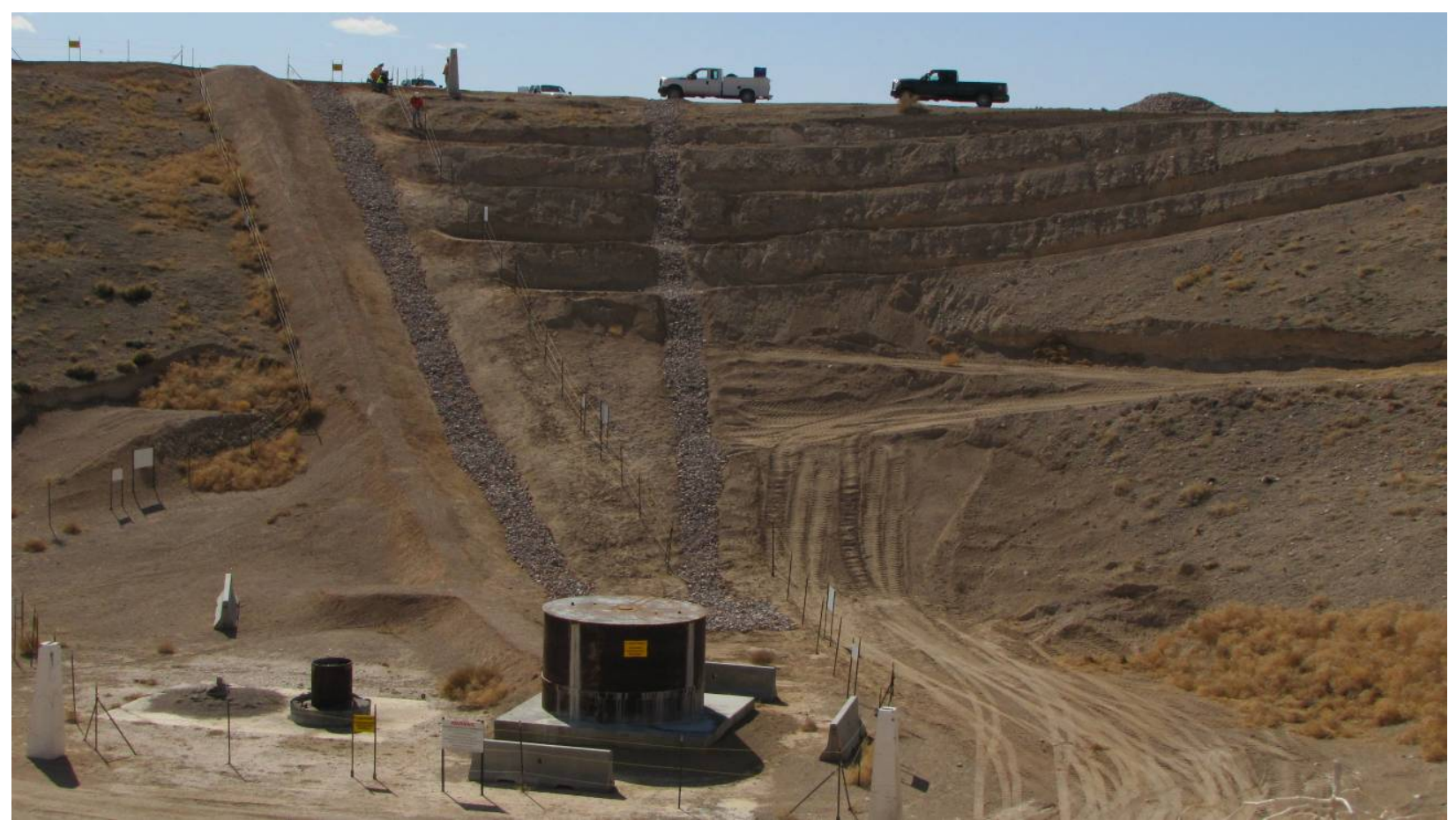

Photograph 35: Completed Work at PLAYER, 03-04-2013 
Addendum to CAU 547 CR

Revision: 0

Date: July 2013

THIS PAGE INTENTIONALLY LEFT BLANK 
Addendum to CAU 547 CR

Revision: 0

Date: July 2013

\section{LIBRARY DISTRIBUTION LIST}


Addendum to CAU 547 CR

Revision: 0

Date: July 2013

\section{THIS PAGE INTENTIONALLY LEFT BLANK}




\section{LIBRARY DISTRIBUTION LIST}

U.S. Department of Energy

Office of Scientific and Technical Information

P.O. Box 62

Oak Ridge, TN 37831-0062

Southern Nevada Public Reading Facility

c/o Nuclear Testing Archive

P.O. Box 98521, M/S 400

Las Vegas, NV 89193-8521

Manager, Northern Nevada FFACO

Public Reading Facility

c/o Nevada State Library \& Archives

Carson City, NV 89701-4285
1 (Uncontrolled, electronic copy)

2 (Uncontrolled, electronic copies)

1 (Uncontrolled, electronic copy) 
Addendum to CAU 547 CR

Revision: 0

Date: July 2013

\section{THIS PAGE INTENTIONALLY LEFT BLANK}

